\title{
A REVIEW OF FINANCIAL REPORTING LIABILITY LAWSUITS IN SINGAPORE
}

\author{
Pelma Jacinth Rajapakse*
}

\begin{abstract}
Accountants and auditors around the world have been subject to professional liability lawsuits, as a result of corporate collapses in the wake of the global financial crisis. Some of the reasons for these corporate collapses and bankruptcies have been related to breaches of contract, professional negligence, and the contravention of statutory duties by financial advisors and the failure of auditors to give a true and fair view of a company's financial position. Auditors are subject to numerous rules and regulations in Singapore. The purpose of this paper is to examine the factors that have caused certified practising accountants and independent auditors in Singapore to be sued by their clients and third party users of financial reports. The answer to this question is of obvious interest to members of the public accounting profession in Singapore and around the world. The major purpose of this paper is to make that question more specific and to gather and analyse evidence that might provide answers. This paper has taken into account lawsuits brought against accountants and auditors in Singaporean courts over the past two decades (1990-2010). It focuses on two types of cases. The first type refers to those where the accountants and auditors were directly sued by their clients, and litigated in a court of law. The second type focuses on matters where the accountants and auditors were not directly sued but were summoned as witnesses or third parties in the litigation.
\end{abstract}

Keywords: Auditor's liability, Singapore, Common law tort, Breach of contract

* B.Com (Honours), Attorney-at-Law, M.A. (Econ) (Waterloo), LL.M. (Monash), PhD (Griffith), Senior Lecturer, Department of Accounting, Finance and Economics, Griffith University, Nathan, Queensland, Australia. The author gratefully acknowledges the research grant offered by the Institute of CPA (Singapore) for this project, and the advice and support provided by the Research Team of ICPAS, Professor of Management Accounting, Dr. Lokman Mia, Professor of Business Law, Dr Eugene Clark of the Griffith Business School and Professor Vivien Beattie, Adam Smith Business School, Accounting and Finance, 


\section{INTRODUCTION}

Accountants and auditors around the world have been subject to professional liability law suits, as a result of many corporate collapses in the wake of the global financial crisis. For example, in 2007, Bear Sterns Asset Management, a large US hedge fund was collapsed and with the failure of Bear Stearns, in 2008, the fourth largest US investment bank Lehman Brothers' shares fell sharply leading to collapse and bankruptcy. After a series of attempted takeover bids, and a finding of fraud in a subsidiary's purchase of another subsidiary, Dynegy Inc., an electric utility company in Texas filed for bankruptcy in 2012. Large audit firms, Deloitte, KPMG, PricewaterhouseCoopers, Ernest \& Young were exposed to litigation as a result of the credit crisis in the companies such as American International Group Inc, Bear Stearns, Countrywide Financial Corporation, Fannie Mae, Freddie Mac, HBOS (Bank of Scotland), IndyMac Bancorp Inc., Lehman Brothers, and Merrill Lynch. ${ }^{1}$

Some examples of corporate collapses in Australia include the failures of Allco Financial Group Ltd, ${ }^{2}$ Centro Retail and Property Trust Group, ${ }^{3}$ Storm Financial Ltd., Opes Group Stock-broking Ltd., ${ }^{4}$ ABC Learning Centres Ltd., ${ }^{5}$ GPT property group, Bell Potter Securities Ltd., Westpoint Group of Companies, ${ }^{6}$ and Babcok and Brown Ltd. ${ }^{7}$ In Singapore, the Open Database of the Corporate World reports that as of February 2014, there are 788 companies in liquidation and compulsory winding up under the regulations of the Singapore Accounting and Corporate Regulatory Authority. ${ }^{8}$

Some of the reasons for these corporate collapses and bankruptcies have related to breaches of contract, professional negligence, and the contravention of statutory duties by

University of Glasgow, Scotland. The research assistance provided by the Doctoral candidate, Ms. Jodi

Gardner of Faculty of Law, University of Oxford is greatly appreciated.

1 Securities and Exchange Commission, 'Enforcement Actions: Addressing Misleading Conduct that led to or arose from the Financial Crisis’ (December 2104) <https://www.sec.gov/spotlight/enf-actions-fc.shtml>.

${ }^{2}$ Allco Financial Group Ltd (receivers and managers appointed) (in liq) (2012) 88 ACSR 328; Economy Australian News, Corporate collapses at record high (28 August 2104)

<http://www.businessspectator.com.au/news/2104/8/28/economy/corporate-collapses-record-high>.

\footnotetext{
${ }^{3}$ Allens and Linklaters, The Centro decision and the approval of financial statements (29 June 2011) <http://www.allens.com.au/pubs/cg/focgjun11_01.htm> .

${ }^{4}$ Hopgood Ganim, The Collapse of Opes Prime Stockbroking Ltd (April 2008)

<http://www.hopgoodganim.com.au/page/Publications/>.

${ }^{5}$ Colin Kruger, Lessons to be learnt from ABC Learning's collapse (2 January 2009)

<http://www.smh.com.au/business/lessons-to-be-learnt-from-abc-learnings-collapse>.

6 ASIC, ASIC settles Westpoint compensation litigation (1 February 2011)

$<$ https://westpoint.asic.gov.au/wstpoint/wstpoint.nsf/byheadline/>.

7 See, Ben Butler, Babcock \& Brown executives misled investors, writ alleges (7 December 2104)

$<$ http://www.smh.com.au/business/banking-and-finance/>.

8 The Open Database of the Corporate World, <https://opencorporates.com/companies/sg? current_status=>.
} 
financial advisors ${ }^{9}$ and the failure of auditors to give a true and fair view of a company's financial position. ${ }^{10}$ A recent report by the House of Lords Economic Affairs Committee that followed an investigation into 'Auditors' Market Concentration and their Role' has revealed several shortcomings in the large-firm audit market in the UK. The Committee's Inquiry unfolded that the 'audit standards are slipping' - the audit standards had been lowered by the adoption of International Financial Reporting Standards (IFRS). These Standards encouraged box-ticking and reduced scope for auditors to exercise judgement to reach a true and fair view. The Committee recommended that prudence be reasserted as the guiding principle of audit. Moreover, the Inquiry found that the breakdown of dialogue between bank auditors and regulators was a 'dereliction of duty' that contributed to the global financial crisis. ${ }^{11}$ These factors indicate the seriousness of the current legal environment for the accounting and auditing profession, government and third parties. ${ }^{12}$

Under the legal system in Singapore, auditors are subject to a vast regime of laws ranging from common law to statute. The Companies Act 1965 of Singapore, and various government agencies and professional bodies such as the Institute of Certified Public Accountants of Singapore (ICPAS), Commercial Affairs Department (CAD), Accounting and Corporate Regulatory Authority (ACRA), Monetary Authority of Singapore (MAS), Corrupt Practices Investigation Bureau (CPIB) and Suspicious Transaction Reporting Office (STRO) regulate the conduct of accountants and auditors through the provision of standards and guidelines.

Due to the many laws which have been imposed on the auditing profession in Singapore, it is argued that auditors in this country are exposed to a greater level of liability as in other countries, such as Australia, the United Kingdom, United States, Canada and New Zealand. This is evidenced from the application of common law and statutes such as the Singapore Companies Act 1965, Finance Companies Act (Chapter 108), Financial Advisors Act (Chapter 110) and the Penal Code (Chapter 224) which effectively extend

\footnotetext{
${ }^{9}$ For the purpose of this study, a 'financial advisor' means both the practising accountants and auditors who engage in private practise as individuals or through a firm of accountants in Singapore. Financial advisors perform many functions, including auditing financial statements, designing financial accounting systems, assisting in managerial accounting function, providing financial and managerial advisory services, and tax preparation. They may perform services for corporations, partnerships, individuals, and other organisations ${ }_{10}$ Ernest Kan, Audit and Assurance - Principles and Practices in Singapore (CCH Asia Pte Limited, $2^{\text {nd }}$ ed., 2010) 25; M. Davies, 'The Liability of Auditors to Third Parties in Negligence' (1991) 14 University of New South Wales Law Journal 171.

11 House of Lords ( UK Parliament), Auditors: Market concentration and their role - Economic Affairs Committee (2011) <http://www.publications.parliament.uk/pa/ld201011/ldselect/ldeconaf/119/11903.htm>.

12 G. Gill et al, Modern Auditing in Australia (John Wiley and Sons, 6th ed, 2001) 94; Vylan Nguyen and Pelma Rajapakse, 'An Analysis of the Auditors' Liability to Third Parties in Australia' (2008) 37 Common Law World Review 9 - 24; Ingrid De Poorter, 'Auditor's liability towards third parties within the EU: A comparative study between the United Kingdom, the Netherlands, Germany and Belgium' (2008) 3(1) Journal of International Commercial Law and Technology 68 - 75; Maggie Rajacic, Pelma Rajapakse and Eileen Webb, 'The Impact of the Trade Practices Act (1974 (Cth) on the Auditors' Liability' (2000) 19 University of Tasmania Law Review 205 - 236.
} 
the liability of auditors to third parties. The White paper published by the Robert Half Financial Leadership Forum states that the chief financial officers in Singapore are under pressure to keep up with the introduction of new regulations across nearly all aspects of corporate activity. ${ }^{13}$ Therefore, reform of the law is necessary in order to limit auditors' liability in Singapore, by introducing systems of proportionate liability and statutory capping in line with international trends. ${ }^{14}$ The outcomes of this research will hopefully generate more knowledge and awareness about the current legal position of accountants and auditors in Singapore.

There are prior studies on professional legal liability of accountants and auditors in Singapore in the context of common law and statutes. ${ }^{15}$ These studies mainly focused on analysing the legal issues and concepts under the common law of negligence and legislation in relation to legal liability of accountants and auditors. However, no prior studies have comprehensively analysed the accounting and auditing related errors and causes for negligent misstatements alleged in the lawsuits against the financial advisors in Singapore. This research is the first comprehensive study in Singapore that investigates the accounting and auditing related issues raised in the lawsuits. Accordingly, this study seeks to fill the gaps in the existing scholarly literature.

The purpose of this research is to analyse 'what factors have caused certified practising accountants (CPAs) and independent auditors in Singapore to be sued by their clients and

\footnotetext{
13 Robert Half Financial Leadership Group, Financial Regulation in Singapore: Challenges, Priorities and Future Directions ( 2012) http://www.roberthalf.com.sg/EMEA/Singapore/Channel\%20Descriptors/rhsg/PDFs/RobertHalf-SG-Financial-Forum-Whitepaper_2012.pdf>; ACCA, Accountancy Future, Audit Reform: Aligning Risk with Responsibility (London: The Association of Chartered Certified Accountants, 2011) http://www.accaglobal.com/content/dam/acca/global/.../tech-af-arar.pdf $>5$.

${ }^{14}$ See generally, K. Cooper, 'Proportionate Liability- 5 years on' A paper presented for The Continuing Professional Education Department of the College of Law, 2010, Sydney, NSW, 8 - 15; M. Duffy, 'Proportionate Liability: A Disproportionate and Problematic Reform' (2003) 60(8) Plaintiff 11-20.

15 ANG Cheng Hock and Kenneth LIM Tao Chung, 'Who left the Gates Unlocked? Reconciling the duties of Auditors and Company Director', (2008) Singapore Academy Law Journal 171-194; Joy Tan, 'Court of Appeal Considers Directors' Duties of Supervision and Management', Singapore Institute of Directors Bulletin (2008) (1), <http://www.sid.org.sg/web_publications/articles_detail/32>, Mayer Brown and JSM, Criminal liability of Auditors: Who is next? (August 2012) < http://www.mayerbrown.com/Criminal-Liability-for-Auditors---WhosNext-08-10-2012/>.

Reference to studies in other jurisdictions include: Vylan Nguyen and Pelma Rajapakse, 'An Analysis of the Auditors' Liability to Third Parties in Australia' (2008) 37 Common Law World Review 9-24; T. Bush, et al, Auditor Liability Reforms in the UK and the US: A Comparative Review (2007)

<http://papers.ssrn.com/sol3/papers>; L. Khoury, 'The Liability of Auditors Beyond Their Clients: A Comparative Study’ (2001) 46 McGill Law Journal 413 - 472. Maggie Rajacic, Pelma Rajapakse and Eileen Webb, 'The Impact of the Trade Practices Act 1974 (Cth) on the Liability of Auditors' (2000) 19 (2) University of Tasmania Law Review 205; S Chua, 'More Thoughts on the Auditor's Liability in Negligence in respect of the Audit Report' (1995) 16 (7) Company Lawyer 195; Clinton Free, 'Limiting Auditors' Liability' (1999) 11 (1) Bond Law Review 118; Helen Anderson, 'Auditors' Liability: Is Misleading and Deceptive Conduct an Alternative to Negligence?' (1999) 17 (6) Companies and Securities Law Journal 350; A Greinke, 'Auditors' Liability to Third Parties: The View of the High Court', (1997) 15 (5) Company and Securities Law Journal 309; K Hogg 'The Tortious Liability of Auditors to Third Parties: A Reassessment' (1994) 18 (1) University of Queensland Law Journal 79; Robert Baxt, 'The Liability of Auditors - The Pendulum Swings Back' (1990) 8 Company and Securities Law Journal 249-57; A. Davidson and A. Khan 'Contractual Liability of an Auditor' (1980) 8 (5) Australian Business Law Review 300.
} 
third party users of financial reports'? The answer to this question is of obvious interest to members of the public accounting profession in Singapore and around the world. The major purpose of this study is to make that question more specific and to gather and analyse evidence that might provide answers.

\section{Research Methodology}

The study considered lawsuits brought against accountants and auditors in Singaporean courts over the past two decades $(1990-2010)$. The research focused on two types of cases. The first type of cases refers to those where the accountants and auditors were directly sued by their clients, and litigated in a court of law. The second type of cases focuses on the matters where the accountants and auditors were not directly sued but were summoned as witnesses or third parties in the court proceedings.

Finding Singapore sources was challenging. In locating the Singaporean cases, the following legal resources were used namely, WestLaw, Asian Legal Information Institute, Legal Workbench (Singapore) and Singapore Academy of Law. Thus, eight Singaporean court cases were located from the above sources. There appeared to be fewer reported cases on the liability of accountants and auditors in Singapore and less success with the relatively few cases that do go to court. This may be a reflection on the different legal systems and the availability of legal remedies for complainants in the jurisdictions in Singapore.

However, all of the eight cases listed below are major court precedents decided by the High Court and the Court of Appeal which are the superior courts Singapore. These cases provide sufficient information for the analysis of factors associated with the law suits against accountants and auditors in Singapore.

Each case was analysed in the following sequences to identify the factors that contributed to the litigation against the accountant/auditor.

(i) Identification of the type of services performed by the accountant or auditor - (e.g. auditing, financial reporting, taxation and reviews of financial planning, management accounting and insolvency);

(ii) Identification of financial reporting errors involved,

(iii) Significance of the financial reporting/advise errors identified, and

(iv) Outcome or conclusion in the case.

The types of alleged errors involved in Singaporean cases generally include the allegations of inadequacy in the interpretation of accounting and auditing standards, lack of independence of the auditor, especially over-reliance on management representations, inadequate training and proficiency for the engagement undertaken, and improper study and evaluation of the internal control system. 
Part I of this paper provides a background to the research and an explanation of the research methodology for case analysis; Part II provides a detailed examination of the factors that contributed to the litigation against the financial advisor. A summary of the factors identified in the case analysis for Singapore are provided in Table $1 .{ }^{16}$ Finally, the paper will close with a summary of the main findings of the study.

\section{ANALYSIS OF THE FACTORS ASSOCIATED WITH LAWSUITS IN SINGAPORE}

The regulatory regime for financial advisors in Singapore is based strongly on the United Kingdom's common law system and supplemented with additional legislation and regulation. The judicial system in Singapore for hearing cases pertaining financial advisors is relatively straightforward. The cases are initially heard by a single judge in the High Court. If one of the parties appeals the High Court's decision, the cases are sent to the Court of Appeal to be heard by a panel of three judges. This court exercises appellate jurisdiction and is the final court of hearing; there are no further appeals available. The following section provides a detailed analysis of the factors associated with the lawsuits against financial advisors in Singapore.

\section{List of Cases - Singapore}

(a) Standard Chartered Bank and Another $v$ Coopers \& Lybrand (sued as a firm) [1993] 3 SLR 712; [1993] SGHC 215

(b) United Project Consultants Pte Ltd v Leong Kwok Onn (trading as Leong Kwok Onn \& Co) [2005] 4 SLR 214; [2005] SGCA 38

(c) JSI Shipping (S) Pte Ltdv Teofoongwonglcloong (a firm) [2007] 4 SLR 460; [2007] SGCA 40

(d) Banque Nationale de Paris v Hew Keong Chan Gary and Others [2001] 1 SLR 300; [2000] SGHC 239

(e) Seagate Technology Pte Ltd and Another v Goh Han Kim [1995] 1 SLR 17; [1994] SGCA 128

(f) Go Dante Yap v Bank Austria Creditanstalt AG [2010] SGHC 220

(g) Ikumene Singapore Pte Ltd \& Anor v Leong Chee Leng (trading as Elizabeth Leong \& Co) [1993] SGCA 50

(h) PlanAssure PAC (formerly known as Patrick Lee PAC) v Gaelic Inns Pte Ltd [2007] 4 SLR 513; [2007] SGCA 41

16 See pages 36-39 of this paper. 


\section{Case Analysis}

\section{(a) Standard Chartered Bank and Another $v$ Coopers \& Lybrand (sued as a firm) [1993] 3 SLR 712; [1993] SGHC 215}

This case was heard by Justice Lai Kew Chai of the High Court of Singapore.

\section{(i) Identification of the Types of Services Performed}

The plaintiffs were bankers at the Standard Chartered Bank. The defendants were accountants who prepared and audited accounts for the plaintiffs. The plaintiffs alleged that the defendants negligently prepared and audited the accounts of PanElectric Industries Ltd and the consolidated accounts of the Pan-El group of companies (Pan-El).

The plaintiffs are well-known bankers in Singapore and had been bankers of PanEl since the 1960's. The defendants were auditors of Pan-El and some of its subsidiaries. They audited Pan-El's accounts for 1983. The report issued on 6 April 1984 stated that the accounts of Pan-El were a 'true and fair' view of the financial position or state of affairs of Pan-El as at 31 December 1983. The report was sent by the defendants to Pan-El, it was not sent to the plaintiffs or any other party. Based on these accounts and financial reports, the plaintiffs extended loans to the group of companies on May 1984. The Bank contended that the accounts did not show a true and fair view of the financial position.

Pan-El went into provisional liquidation on 6 February 1986 and then into liquidation on 9 October that year. Standard Chartered Bank claimed economic losses suffered in respect of loans which they had extended having relied on what the information provided by the defendants.

There was no contractual relationship between the plaintiff and the defendants. Therefore the plaintiffs had to sue the defendants on the basis of negligent misstatement and pure economic loss under the law of torts. The plaintiffs alleged that the defendants should have known that they (the plaintiffs) would inevitably rely on audited accounts of Pan-El and that by March/April 1984 it was well known in Singapore banking and accounting circles that the plaintiffs were contemplating making a substantial loan to the Pan-El group.

(ii) Identification of Financial Reporting Errors 
The financial reporting error is in relation to the defendant's allegedly negligently preparing and auditing the accounts. The plaintiffs argued that the auditor's report stated the accounts represented a 'true and fair' view of the financial position or state of affairs of Pan-El, the borrower company and of the group, but they in fact were not. Whilst the specific details are not provided in the actual court proceedings, it is likely to be allegations of inadequacy in the interpretation of accounting and/or auditing standards in preparation of the financial report.

\section{(iii) Significance of the Financial Reporting/Advice Errors Identified}

There was little or no significance of the financial reporting errors identified in the proceedings. This is because matter was struck-off due to lack of proximity in relationship between the borrower company Pan-EI and the auditors and therefore the alleged errors were not discussed in any depth. This case did not involve a full hearing of the matter as it was only related to the application to amend the plaintiff's statement of claim. However it is very important as it shows that the strict line that the Singapore courts have taken in relation to auditor liability to third parties. Even though there was minor evidence to show that the auditors (arguably) should have been aware of the potential of Pan-El obtaining a loan from the plaintiffs, this was not sufficient to show a reasonable prospect of success in a full trial. It shows that the Singapore Courts are going to strictly and completely follow Caparo Industries plc v Dickman \& Others ${ }^{17}$ decision regarding liability of auditors. In this case the facts did not overcome the hurdles of the Caparo decision. As outlined by Justice Lai Kew Chai:

The court was satisfied that for reasons of adhering to strict doctrine as enunciated in Caparo the sub-category of tortious liability for economic loss arising out of an auditor's misstatement should not be extended to lenders, existing or potential, where in truth and in substance the auditors are performing the statutory duty of rendering an auditors' report for the protection of shareholders and no more. ${ }^{18}$

Even though the Courts have taken this strict approach, it is interesting to note that the auditors in this case still had to go through two rounds of litigation. Litigation is expensive, time consuming and (regardless of the outcome) can have significant reputational detriment to the companies involved. It would be useful to understand why these cases that have no reasonable prospects of success are coming before the Courts? There are a number of possibilities - an attempt to change the existing laws, lack of understanding of legal rights, inappropriate advice from lawyers. It is probably important to look into this issue in an attempt to prevent any further unsuitable litigation.

17 [1990] 1 All ER 568.

18 Ibid. 
The plaintiff bankers claimed against the defendants on the basis of negligent misstatement. Instead of a defence, the defendants applied for an order that the plaintiffs' statement of claim be struck out on the principal ground that it disclosed no reasonable cause of action. Justice Lai Kew Chai outlined that for a claim of negligent misstatement there must be a sufficient 'relationship of proximity' and it must be just and reasonable to impose liability on the potential defendant. The auditors completed their report in compliance with their statutory duties under the Companies Act. The cases of Caparo and Al Saudi Banque \& Ors v Clerk Pixley (a Firm $)^{19}$ were required to be followed by the Singapore High Court. These cases stated that in claims of pure economic loss reasonable foreseeability is not sufficient. His Honour therefore struck out the claimant's statement of claim. After this occurred, Counsel for the plaintiffs applied for leave to amend the statement of claim.

The plaintiffs argued that the prevailing commercial context meant that the defendants must have known that their audited accounts of Pan-El would have been used by potential lenders (including the plaintiff Bankers) to consider extending loans to Pan-El. They then submitted that this was sufficient proximity for the defendants to owe the plaintiffs a duty of care regarding the auditor's reports.

The judge discussed the development of negligence and tort law and stated that the 'tort of negligence should only be extended pragmatically and incrementally.' The cases of Caparo and Al Saudi Banque have brought into sharp focus the limits on liability for economic loss caused by negligent misstatements. Justice Lai Kew Chai then discussed the case of Caparo and outlined that in that case, the Court made it very clear that foreseeability or high foreseeability that a person or a group of persons may rely on the statements of an auditor was by itself not sufficient. His Honour quoted Lord Bridge, who stated:

the 'limit or control mechanism ... imposed upon the liability of a wrongdoer towards those who have suffered economic damage in consequence of his negligence' rested in the necessity to prove, in this category of the tort of negligence, as an essential ingredient of the 'proximity' between the plaintiff and the defendant, that the defendant knew that his statement would be communicated to the plaintiff, either as an individual, or a member of an identifiable class, specifically in connection with a particular transaction or transactions of a particular kind (eg in a prospectus inviting investment) and that the plaintiff would be very likely to rely on it for the purpose of

19 [1990] 2 WLR 344; [1990] Ch 313. 
deciding whether or not to enter upon that transaction or upon a transaction of that kind. $^{20}$

The defendants submitted that there is only relationship of proximity if the statements were made for the purpose for which the plaintiffs relied on. In this case the reports were provided to Pan-El under its obligations in the Companies Act and therefore there reasons were entirely separate to the plaintiff's loans to the company. Therefore the judge held that there was no proximity and thus no duty of care was owed to the plaintiff by the auditors.

(b) United Project Consultants Pte Ltd v Leong Kwok Onn (trading as Leong Kwok Onn \& Co) [2005] 4 SLR 214; [2005] SGCA 38

This was an appeal from the decision of Justice Lai Kew Chai to the Singapore Court of Appeal. It was heard by Justice of Appeal Chao Hick Tin, Justice Tay Young Kwang and Chief Justice Yong Pung How. The unanimous decision was delivered by Yong Pung How CJ.

\section{(i) Identification of the Types of Services Performed}

The appellant (originally the plaintiff) was a private limited company provided engineering services. The respondent (originally the defendant) was the appellant's auditor and tax agent. The respondent was appointed as the appellant's auditor and tax agent in 1983 and acted in that capacity until the middle of 2000. From the company's inception in 1983 to 1998, the appellant had adopted certain practices in relation to the treatment of directors' fees and tax returns. In the middle of each calendar year (the end of the financial year), the appellant's board of director would determine how much profits were made in the course of the year and would accordingly declare a certain sum as directors' fees. Part of this fee was distributed to the directors and the remained was put in a fixed deposit account. This account accrued, subject to any additional future distributions to the directors. In the appellant's books, the retained fees were recorded as a sum owing to the directors.

At the beginning of each of the following calendar years, the income tax forms issued by the appellant to its directors only declared the paid fees and did not declare the additional fees retained in the fixed deposit account. Unfortunately, the appellant treated both amounts as fees and therefore as a deductible expense for the purpose of income tax assessment. This meant that neither the appellant nor its directors had to account for the tax on the retained fees.

20 [1990] 1 All ER 568, 576. 
The respondent acted as the auditor of the company and had in that capacity certified the appellant's accounts reflected a true and fair view of the company's financial state of affairs. He also attended to the appellant's income tax matters, including the filing of the tax returns.

In 1992, the appellant decided to make an additional allocation of directors' fees from the retained fees. Once the fees were paid, it was determined that the payments should then be notionally spread of the previous years and retrospective additional tax forms should be prepared by the appellant to declare the fees. The appellant organised for this to occur, submitted the relevant forms and paid the additional taxes. The Inland Revenue Authority of Singapore (IRAS) did not make any adverse findings about this process. The same process occurred in 1997 and again, the IRAS did not comment.

However, in July 1998 the IRAS queried the appellant about the directors' fees from 1997. After meeting with the IRAS, the respondent suggested that the appellant should distribute all the retained fees and issue additional forms relating back to the years of assessment 1990 to 1997. This was done and the IRAS imposed a penalty of $\$ 1.707$ million on the appellant (the same amount as the tax payable).

\section{(ii) Identification of Financial Reporting Errors}

The financial reporting errors related to this case were an inability to fully understand the requirements of the Income Tax Act and a failure on the part of the audit firm to warn of the consequences of the filing an incorrect return. These are likely to be related to inadequate training and proficiency for the engagement undertaken by the auditor. ${ }^{21}$

(iii) Significance of the Financial Reporting/Advice Errors Identified

The Court of Appeal held that the respondent auditor had failed to warn the appellant of the potential tax consequences and therefore had breached his duties as a professional tax agent. Therefore the financial reporting errors identified were very significant to the judge's finding. 


\section{(iv) Outcome or Conclusion in the Case}

The appellant commenced an action against the respondent seeking compensation for losses which it allegedly suffered because of a breach of contractual duty and/or a breach of duties in tort.

The defendant auditor relied on four arguments; (1) there was no duty of care, (2) there was no breach, (3), if there was a breach, it did not cause the loss, (4) there was a bar to recovering damages by operation of the maxim ex turpi causa non oritur actio: this is a legal doctrine which states that a plaintiff will be unable to pursue a cause of action if it arises in connection with his/her own illegal act.

The trial judge held that the auditor was not required to know the distribution of directors' fees as he only received the form from one director (to whom he did the personal taxes for) and not the other directors. It was further outlined that the respondent's involvement as an auditor took place in the middle of the calendar year, whereas the duties of a tax agent occurred at the start of the following calendar year. This meant that the treatment of the director's fees as a company expense and in manner in which the directors had declared their income for tax assessment was not reviewed concurrently.

The Courts therefore decided that it was the company's obligation (not the tax agent's) to ensure that the tax forms reflected the directors' declared fees. As the preparation and issue of the forms were carried out by the appellant's internal accountant and there was no away for the respondent to have known the actual amounts paid to each director, it was not the respondent's duty to detect these errors on the forms.

The trial judge also held that there was no causation of loss by the respondent as the company knew what they were doing and were trying to evade having to pay tax on retained fees. His Honour also held that damages were barred as the maxim ex turpi causa non oritur actio was not limited to illegal acts, but included acts that were regarded as socially unacceptable. It was therefore held that there was no basis to award any remedy to the appellant that would relieve it from the known consequences of its actions at the expense of the respondent who could not have detected the breaches and prevented them.

On appeal, the issues set out by the appellant were:

${ }^{21}$ See also, Ameeta Jain and Dianne Thomson, 2008, 'Corporate Governance, Board Responsibilities and 
- whether the respondent auditor, in the circumstances, knew that there were errors in the directors' IRAS forms for the calendar years 1990 to 1997;

- if so, whether there was a duty imposed upon the respondent to warn the appellant of the tax consequences and to advise it to issue the proper IRAS forms to each director;

- whether the respondent was in breach of his duty in (b) above;

- whether the respondent had caused the penalty imposed by IRAS and therefore the loss suffered by the appellant; and

- whether the appellant should be barred from recovery against the respondent by virtue of the doctrine of ex turpi causa non oritur actio.

\section{- Knowledge of the error committed by the appellant}

The Singapore Court of Appeal noted that appeal courts should not interfere with the trial judge's finding of fact unless it can be shown that they were plainly wrong. However if this does occur, the Court of Appeal will be free to evaluate the evidence and make its own decision.

The Court commented that the trial judge should not have focused on whether the respondent should have submitted the forms but whether circumstances were such that it was incumbent on the respondent to warn the appellant against the consequences of its acts. The trial judge also noted that the manner in which the director's fees were apportioned was never disclosed to the respondent. The Court of Appeal however found differently. It stated that from 1993 onwards, the respondent was submitting the tax returns of one of the directors (Ken Tan) and therefore had actual knowledge of the fee structure for the directors.

\section{- Whether there existed a duty to warn}

The Court of Appeal held that it was more appropriate to deal with this issue in the respondent's capacity as the appellant's tax agent (as opposed to its auditors). It highlighted the restrict approach taken by the court when determining cases of pure economic loss as outlined in Hedley Byrne v Heller \& Partner ${ }^{22}$ and Caparo. After carefully analysing the relevant case law in Singapore and the United Kingdom, the Court held that the touchstone for liability is 'proximity', stating that:

before liability may be imposed upon a defendant for pure economic loss, a court must be satisfied that all the circumstances of the case give rise to a relationship whereby the defendant owes a duty to the plaintiff to avoid the particular loss

Financial Performance: The National Bank of Australia' (2008) 6(2) Corporate Ownership \& Control 99-113. 
suffered by the plaintiff. In doing so, the court must likewise be satisfied that there are no policy reasons why such a duty ought not to be imposed. ${ }^{23}$

The respondent's duties as a tax agent were to 'file the appellant's tax returns and to ensure that the returns complied with the requirements under the Income Tax Act.' The question is therefore whether the duty to warn the appellants fell within that responsibility. The Court emphasised that a tax agent is not responsible for the mathematical calculations of the directors' fees however they have a duty to ensure that the client does not submit incorrect tax returns. It outlined that the respondent's own expert witness stated that it would have warned directors to declare their income correctly and issue proper forms and that a tax agent who is a certified accountant should warn clients of potential tax penalties for incorrect information. The Court therefore held that the respondent had a duty to warn of inaccuracies in the filing of tax returns should he acquire any knowledge to that effect.

\section{- Whether there was a breach of the duty of care}

The Court of Appeal held that the respondent had failed to warn the appellant of the potential tax consequences and therefore had breached his duties as a professional tax agent.

\section{- Whether the breach caused the loss}

The Court held that after the respondent was aware of the fee structure (in 1993), he had a duty to warn the appellants. As he did not do this, the cause for the loss thereafter was due to the imposition of, and subsequent failure in, the respondent's duty as tax agent.

\section{- Whether the defence of illegality is applicable}

There is a defence of illegality - the maxim ex turpi causa non oritur actio. The respondent claimed that the appellant is barred from remedies as it occurred in the commission of a statutory offence. This defence is invoked when the plaintiff has acted in a way that is illegal or has some aspect of moral culpability. The Court held that the tax minimisation actions of the appellant were not so reprehensible that it should attract the application of the illegality defence. In addition, the appellant's loss was precisely the kind that the respondent could have prevented. Therefore the Court of Appeal did not obstruct the appellant from obtaining remedies. The Court held that the appellant were responsible for all losses that 
occurred until 1992 but ordered that the respondent tax agent pay damages that occurred from 1993 onwards. The respondent was also required to pay 80 per cent of the appellant's costs.

\section{- Additional Comments}

Singapore Courts have strictly followed the United Kingdom's decisions on cases involving auditors' professional liability to third parties (indirect clients). Pure economic loss cases are very restrictive and the courts are generally hesitant to find that the auditor has been negligent.

However, in this case, the Court of Appeal overturned a trial judge's decision that the tax agent/auditor was not liable in negligence for pure economic loss. Because in this case the tax agent/auditor reported directly to the plaintiff company, therefore there was no issue of third party liability ${ }^{24}$. The Singapore Court of Appeal was also willing to find that auditors and tax agents have a duty to warn of potential illegal actions. This is consistent with the development of duty of care in other jurisdictions.

(c) JSI Shipping (S) Pte Ltd v Teofoongwonglcloong (a firm) [2007] 4 SLR 460; [2007] SGCA 40

This case was heard by the Court of Appeal of Singapore. There were three justices who heard the case - Chief Justice Chan Sek Keong and Justices of Appeal Andrew Phang Boon Leong and V K Rajah. Justice V K Rajah delivered the judgement of the Court.

\section{(i) Identification of the Types of Services Performed}

The appellant is JSI Shipping, which is a business of providing freight-forwarding and other related services. There were two directors, Riggs and Cullen who resided in California. JS International Shipping Corporation was the ultimate holding company of the appellant and provided international logistics and door-todoor freight-forwarding services to its mainly US-based customers. Because of the increasing business in Singapore JS International decided to incorporate a local subsidiary instead of continuing to use local agents. The appellant was therefore incorporated on 26 September 1998 and Riggs was engaged to head the appellant

[1964] AC 465, [35].

24 See, Standard Chartered Bank and Another v Coopers \& Lybrand (sued as a firm) [1993] 3 SLR 712. See further, P. Carl, H. William and S. David, 'Auditor liability to third parties: an international focus' (2000) 15(8) Managerial Auditing Journal 394 - 407. 
and oversee the Asia operations. The respondent is Teofoongwonglcloong, an established firm of Singapore certified public accountants which provided services including statutory auditing, special auditing, accounting and tax and corporate advisory services.

\section{- Appointment of defendant auditors}

The appellant hired the respondent to conduct three statutory audits of the appellant's accounts regarding the financial years 1999, 2000 and 2001. The audits were all unqualified and the terms of appointment provided as follows ${ }^{25}$ :

Our audit will be made in accordance with the requirements of Section 207 of the Companies Act, Cap. $50^{26}$ with the objective of expressing an opinion on the accounts.

In forming our opinion on the accounts, we will perform sufficient tests to obtain reasonable assurance as to whether the information contained in the underlying accounting records and other source data is reliable and sufficient as the basis for the preparation of the accounts. We will also decide whether the information is properly communicated in the accounts. In this regard, we will disclose significant deviation if the accounts do not comply with the Statements of Accounting Standard issued by the Institute of Certified Public Accountants of Singapore.

Because of the test nature and other inherent limitations of an audit, together with the inherent limitations of any system of internal control, there is an unavoidable risk that even some material misstatement may remain undiscovered. Accordingly, our audit should not be relied on to disclose fraud, defalcations or other irregularities. However, if they exist, their disclosure may result from the audit tests we undertake. We shall report to you any such matters and any material weaknesses in the system of accounting and internal control, which come to our notice and which we think should be brought to your attention.

The Companies Act provides that the responsibility for the preparation of the accounts including adequate disclosure is that of the directors. This includes the maintenance of adequate accounting records and internal controls, the selection and application of accounting policies, and safeguarding of the assets of the Company. As part of the audit process, the auditors will request from the directors written confirmation concerning representations made to them about the audit.

25 Quoted from [6] of JSI Shipping (S) Pte Ltd v Teofoongwonglcloong (a firm) [2007] 4 SLR 460; [2007] SGCA 40.

26 The provision states: (1) An auditor of a company shall report to the members on the accounts required to be laid before the company in general meeting and on the company's accounting and other records relating to those accounts and if it is a holding company for which consolidated accounts are prepared shall also report to the members on the consolidated accounts. 
The Companies Act provides that we shall have a right of access to the accounting and other records including registers of the Company. In addition, we have access to such information and explanations as we require for the purposes of our audit. In this connection we look forward to full co-operation with your staff.

The Court of Appeal noted that the letter is very similar to the template provided in the Singapore Standards on Auditing, which is published by the Institute of Certified Public Accounts of Singapore. However, the defendant auditors have provided an additional duty to report any material weaknesses in the system of account and internal controls which came to their attention. This part of the letter is highlighted in italics above.

\section{- Employment structure of the appellant}

As outlined above, Riggs was the Head of the company and reported to Cullen on all operational and business issues. Hora was a trained accountant and JS international's director of finance. He assisted Cullen on financial matters and monitored the appellant's monthly management accounts regularly. The appellant's accounting manager, Wah, prepared the monthly accounts detailing the appellant's expenses.

\section{- Actions by the director Riggs}

Around May 2002, Cullen received an anonymous letter which imputed Riggs and a few other employees in unlawfully engaging in a competing business and misappropriating funds from the appellant. This letter was subsequently found to be from the appellant's office manager who had noticed a number of questionable transactions but was concerned for her job security so sent the letter anonymously.

Cullen went to Singapore to investigate these matters and found that funds had been misused and confronted Riggs. As a result, Riggs resigned on 21 June 2002 and confessed to the misappropriation of funds. A police report was lodged with the Commercial Affairs Department.

The appellants wanted to determine the extent of Riggs's actions. In early July 2002, it engaged $\mathrm{Ng}$ Lee \& Associates to conduct a special audit to ascertain the full extent of the issue. The report stated that Riggs misappropriated company funds amounting to $\$ 1,808 \mathrm{~m}$ during the relevant period. This occurred in a number of ways including:

- personal expenses charge as director's benefits without board approval;

- unsubstantiated travelling expenses;

- doubtful charges for office renovations; 
- fictitious payments to a company controlled by Riggs; and

- unauthorised issuance of numerous cash cheques for fictitious transactions.

A second report revealed that Riggs had also been overpaid by a significant amount and had received also non-approved sums of money for allowances and other benefits. The auditors Teofoongwonglcloong failed to check Riggs's pay against his employment contract to determine whether he was being paid in accordance with his contractual requirements.

\section{(ii) Identification of Financial Reporting Errors}

The case was related to lack of required independence of the auditor, especially over-reliance on management representations. The appellant claimed that all its losses were caused by the respondent auditor's breach of its obligations. This arose from three main actions. Firstly, the respondent had been in substantial doubt as to Riggs's entitlement to the salary and benefit attributed to him. Despite this, it had failed to obtain sufficient appropriate audit evidence to remove such doubt. Alternatively, it had not planned and performed its audits with sufficient professional scepticism.

Secondly, the respondent had failed to express a qualified audit opinion or disclaimer that would serve to highlight the limitation of the scope of its audit and the existence of any factors which prevented it from obtaining sufficient appropriate audit evidence.

Finally, the respondent had failed to advise the plaintiff that in the office there were a number of questionable practices, including:

- splitting payment of invoices of more than $\$ 12,000$ to circumvent the single cheque statutory limit;

- signing of blank cheques; and

- having large prepayment accounts with transactions that had no substantiating documents.

Because of these practices, the appellant stated that the respondent auditor had breached its contract and duty to bring to its attention the weaknesses in the system of accounting and internal control.

\section{- Auditors' response to the claim}

The defendant claimed that it carried out all three of the appellant's audits in accordance with the statutory requirements as it had: 
- planned and performed the audit with a view to obtaining reasonable assurance about whether the financial statements were free of material misstatement;

- undertaken an examination of evidence supporting the amounts and disclosures in the financial statements on a test basis; and

- assessed the accounting principles used and significant estimates made by the directors, as well as evaluated the overall financial statement presentation.

\section{- Evidence produced by parties}

Both parties produced expert evidence from the auditing profession that supported their case. The appellant's expert, Michael Chin, reviewed the audits and stated that they amounted to a breach of the defendant's contractual obligation. As an example, the respondent auditors were unable to obtain a number of documents regarding Riggs's remuneration but had not provided a qualified opinion or disclaimer on this matter. The auditors were also aware of Riggs's ability to write cheques of up to $\$ 12,000$ himself but did not highlight this as internal control weakness.

In contrast, the respondent auditor's expert, Kaka Singh, held that the work carried out by the respondent was adequate and sufficient to give it a reasonable basis to express an unqualified opinion on the financial statements. Singh made a number of observations in support of this, including the fact that the appellant was a wholly-owned subsidiary and therefore closely monitored and had a low audit risk, an audit was inherently imprecise and only looked at a sample of the balances and transactions and that auditors were entitled to rely on the management to provide honest explanations. Singh stated that auditors could not be expected to detect fraud involving collusion amongst employees or by management.

\section{(iii) Significance of the Financial Reporting/Advice Errors Identified}

The Court considered in significant detail appropriate standard of care expected of an auditor, referring the relevant common law, regulations and statutory provisions. ${ }^{27}$ It was held that the appropriate standard is that the auditor must exercise reasonable care and skill of an ordinary skilled person embarking on the

${ }^{27}$ JSI Shipping (S) Pte Ltd v Teofoongwonglcloong (a firm) [2007] 4 SLR 460; [2007] SGCA 40, [32] - [48]. 
same engagement. The duty is not to provide a warranty that the company's accounts are substantially accurate, but to take reasonable care to ascertain that they are so. The precise degree of scrutiny and investigative effort which constitutes reasonable care is to be determined on the facts of each individual case.

After this occurred, the Court stated that it is important to remember the it 'must always guard against the 'scapegoat effect' that often magnifies ex post facto and makes plausible culpability by employing the spectacles of hindsight. ${ }^{28}$ It is important that auditors do not become scapegoats of fraudulent employee's actions.

Therefore the failure to act with adequate independence was considered highly significant by the courts. Auditors are expected to act independently at all times, but not to the extent that they are expected to second-best everything that is told to them or to suspect fraud, unless there is a good reason to not to do so. ${ }^{29}$

(iv) Outcome or Conclusion in the Case

\section{- $\quad$ Trial at first instance}

At the first instance, the trial judge accepted Singh's evidence in its entirety and found that the respondent had conducted the three audits in question without breach of duty or negligence. His Honour proceeded on the basis that 'there would be no breach of duty if the auditor has acted in accordance with a practice accepted as proper by a body of skilled and responsible auditors.' 30

\section{- Basis of Appeal}

The alleged breach of duty can be broadly attributed to three main areas of the audit, namely: (a) the failure to verify Riggs' entitlement to remuneration; (b) the failure to report abuses by Riggs of the cheque signing limit; and (c) the failure to properly verify the renovation expenses of the appellant's warehouse in Singapore and its Hong Kong subsidiary.

\section{- Findings in the Case}

The Court of Appeal determined that the audits had largely occurred in accordance with the auditor's obligations under their contract. However, there was a crucial

\footnotetext{
28 Ibid, [69].

29 See generally, Treasury, 2006, Australian Auditor Independence Requirements (2006)

$<$ http://archive.treasury.gov.au/documents/1184/PDF/Australian_Auditor_Independence_Requirements >

30 Ibid, [68].
} 
issue regarding the auditor failing to verify Riggs' entitlement to remuneration. Riggs was the only director in Singapore whose remuneration and benefits amounted to more than half a million dollars, which was significantly above the standard wage for his position. The evidence was not clear on this point, but it appears that when the auditors required Riggs' employment contract, he either refused to provide it, or stated that he did not have a copy.

The Court outlined that even if the auditors could not have obtained a copy of Riggs' employment contract and remuneration details, the extraordinarily high wages being received meant that they should have qualified their audit reports by highlighting these issues. This would have allowed further investigations to occur, if it was determined to be necessary by the business.

It therefore partly allowed the appeal and awarded the appellant 50 per cent of the losses occasioned by the auditor's failure to verify Riggs' entitlement to remuneration, amounting to a total sum of $\$ 273,385.65$.

\section{- Additional Comments}

This case is very relevant to the auditing and liability issues that are the basis of the current project. As outlined by Justice V K Rajah in the introduction of His Honour's judgment,

This judgment clarifies and restates the law of professional negligence in the context of statutory audits. More specifically, it evaluates the standard of care expected of an auditor in relation to the objective verification of relevant financial particulars and discusses the principles of causation applicable in a claim for damages against auditors. ${ }^{31}$

In concluding their decision, the Court stated that this case (in conjunction with PlanAssure PAC v Gaelic Inns Pte Ltd, discussed below) has caused some concern about the 'prevailing professional standard of public accountants in Singapore. ${ }^{32}$ It highlighted that only one third of the 110 public accountants received a 'good' rating in a public report published by the Accounting and Corporate Regulatory Authority in July 2007. A third of the accounts received a 'satisfactory' rating and the final third were required to undertake immediate remedial steps in their business. The Court therefore stated that 'it is important that the accounting profession promptly takes collective steps to address existing shortcomings in the application of its prescribed standards. ${ }^{33}$

\footnotetext{
${ }^{31}$ Banque Nationale de Paris v Hew Keong Chan Gary and Others [2001] 1 SLR 300, [1].

${ }^{32}$ Ibid, [183].

${ }^{33}$ Ibid, [184].
} 
This case is also a unanimous verdict of the Singapore Court of Appeal and therefore will have significant binding / persuasive authority on future cases.

(d) Banque Nationale de Paris v Hew Keong Chan Gary and Others [2001] 1 SLR 300; [2000] SGHC 239

This case was heard by Justice Lai Kew Chai of the High Court of Singapore. The parties are numerous and complicated, so a summary of the case is provided below. The Plaintiff is a multinational Bank incorporated in France. It was restricted to operate only a branch in Singapore and carried out a banking business. The First defendant (Hew) was an employee Accountant of Banque Nationale de Paris for approximately 10 years before he was dismissed. He was the assistant Vice President of the bank's Private Banking Accounts Department. The Second defendant (Nancy) is wife of the first defendant but they stopped living together in 1995. In December 1996 (on request of Hew), she opened a Singapore dollar current account with the plaintiff Bank. The Third defendant (Tan) is the elder brother of Nancy. He became a customer of the plaintiff Bank in May 1994 and Hew had control of his account.

\section{(i) Identification of the Types of Services Performed}

Hew had control of the accounts of both Nancy and Tan. These accounts were handled very poorly due to Hew trading in shares for himself, and both of the accounts owed the plaintiff Bank significant sums of money. In October 1998, Hew entered into speculative foreign exchange transactions in the names of the second and third defendant, Nancy and Tan totally US \$9 million. The transaction was based on the popularly held belief that the Japanese Yen would weaken, and Hew anticipated huge profits and saw this as an opportunity to recoup the losses sustained in the accounts of Nancy and Tan. These transactions were a significant breach of the Bank's protocols as Hew was not allowed to trade in this manner. They also occurred without the formal authorisation of Nancy or Tan.

The Yen actually strengthened against the US dollar and the transaction resulted in significant losses. When Nancy and Tan realised what had happened, they contacted the plaintiff and stated that they were not aware and had not authorised Hew to enter into the transactions. They also contacted the police and lodged a report on 17 October 1998. On 20 October 1998, the plaintiff also contacted the police and issued a report. 
On 28 October 1998, the plaintiff commenced legal action against Hew and also obtained a Mareva injunction $^{34}$. Hew was charged with seven offences regarding his trading. Hew pleaded guilty to three charges of unauthorised trading and was sentenced to 12 months imprisonment.

Unlike the majority of cases in this area, Banque Nationale de Paris v Hew Keong Chan Gary is alleged breach of fiduciary duty and not alleged negligence. This case raises the issue of where a third party customer is liable to account for a loss sustained by a Bank (principal) as a result of a third party customer inducing or assisting a Bank's fiduciary (an employee accountant) in the commission of a breach.

\section{- Bank's Claim against Nancy and Tan}

The plaintiff Bank claimed against both Nancy and Tan for the outstanding amount due and payable under their accounts. This is based on five causes of action, which are:

- Nancy and Tan's liability for dishonestly assisting Hew to breach his fiduciary duties of good faith owed to the Bank;

- breach of the duty to inform the Bank of Hew's unauthorised transactions;

- express or general authorisation of Hew's foreign exchange activities;

- procuring a breach of Hew's employment contract with the plaintiff; and

- conspiring with Hew to conduct foreign exchange transactions or enter into purchase and sale transactions of shares in their respective names and on their respective accounts.

- Counterclaim by Nancy and Tan

Nancy counterclaimed against the plaintiff Bank on three different grounds:

- in the contract for private banking services there is an implied term that the Bank would exercise all due and professional skill and care in handling her accounts;

- the plaintiff was in breach of an implied term or duty of care under the law of tort; and

- the plaintiff breached its fiduciary duties owed to Nancy as a private banking customer.

\footnotetext{
34 This is a Court order that temporarily restrains the alleged debtor from dealing with some or (rarely) all of their assets in any way which may prevent recovery of the alleged debt, pending hearing of the action for recovery of the debt.
} 
Tan counterclaimed on similar actions to Nancy - that the plaintiff Bank had breached its contractual duty to exercise professional skill and its duty in tort, and that the plaintiff had breached its fiduciary duties. Both Nancy and Tan believed that it was 'a series of control weakness and judgmental failures which occurred at various levels of management of the plaintiff Bank were primarily the causes of the plaintiff's losses as a result of the unauthorised shares and forex trading., 35

\section{(ii) Identification of Financial Reporting Errors}

There were three different potential errors identified in this case. Firstly, Hew's alleged errors - which was the improper study and evaluation of the risk of currency transfers, as well as a failure to adequately warn of these risks. Secondly, Nancy and Tan's alleged errors - which were related to the alleged assistance of Hew's actions. There were also errors by the plaintiff Bank identified in the judgment. This included failure of internal control mechanisms and inadequacy of compliance processes.

(iii) Significance of the Financial Reporting/Advice Errors Identified

Hew's alleged actions were not questioned and the court obviously found his fraudulent actions very significant. The court put significant emphasis on the control weaknesses and judgmental failures of the management of the plaintiff Bank. Therefore the significant error was a failure of internal control mechanisms of the Bank as opposed to any specific individual's actions. As outlined below, His Honour stated Bank's failure to close the account 'was as unfortunate as it was the most causative of the web of causes, of which Hew's rogue behaviour was the other main contributory factor.' 36

\section{(iv) Outcome or Conclusion in the Case}

His Honour was quite scathing of the plaintiff Bank's breaches of protocols in relation to Nancy and Tan's accounts. For instance, Nancy's account was opened up without following adequate processes or risk management and no steps were taken to close this account before significant losses were incurred. For example, His Honour stated plaintiff's failure to close the account 'was as unfortunate as it was the most causative of the web of causes, of which Hew's rogue behaviour was the other main contributory factor.' 37

${ }^{35}$ Banque Nationale de Paris v Hew Keong Chan Gary and Others [2001] 1 SLR 300, [114].

${ }^{36}$ Ibid, [118].

${ }^{37}$ Ibid, [119]. 
In addition, the plaintiff's Auditor Long Form's Report stated:

The Internal Audit Department of the Branch has carried out an investigation and submitted investigation reports to the management. The private banking officer allegedly put through FX deals since March 1998, possibly with the customers' knowledge. The customers concerned did not have any approved FX trading lines with the Branch. The unauthorised deals would have been detected earlier if the Risk Manager for private banking had performed documented control procedures as soon as they occurred. It is clear that he failed to perform these controls and the unauthorised FX transactions continued until October 1998.

In addition to this, the transaction breached a number of other bank protocols. This included the fact that all forex transactions should have the approval of the customer, the clients had not signed the 'Risk Disclosure Form' and the transactions exceeded the express limit of US $\$ 500,000$ of any single instruction.

The Courts therefore commented that the facts which emerged during the trial point to the stark reality that Hew was the sole person responsible for each and every one of the unauthorised share or forex transaction which were booked in the names of Nancy and Tan. He alone decided what shares to buy and to sell and at that price. He placed the orders for each forex trade and often, most certainly the 7 October 1998 forex contracts for which the plaintiff seeks to attach dishonest accessory liability on Nancy and Tan, the orders for the forex trades were placed at first on a 'no-name basis' with the plaintiff's dealers who, contrary to very firm and clear control documented procedures, accepted those orders and effected the deals. Hew entered into those unauthorised share transactions solely for his own benefit and he engaged in the unauthorised forex transactions in the vain hope that he could earn enough profits and trade Tan's account out of the woods. ${ }^{38}$

Whilst the evidence of Nancy and Tan indicated that they were aware to some degree of what Hew was doing, the Court came to the conclusion that this was not sufficient to provide them with a positive duty to the plaintiff, or to make them liable for Hew's actions under third party accessory.

The Courts therefore held that all the transactions were unauthorised and the losses remaining in the accounts of both Nancy and Tan were to be borne by the Banque de Paris. The unauthorised debits and credits in those accounts were reversed accordingly. All securities and collateral furnished by both Nancy and Tan were returned to them freed from all encumbrances. ${ }^{39}$

\section{- Additional Comments}

\footnotetext{
${ }^{38}$ Ibid, [159].

${ }^{39}$ Ibid, [182].
} 
This case follows the English law regarding the liability of third party customers closely. ${ }^{40}$ The judge was obviously very hesitant to make bank customers liable for actions that occur in their accounts, regardless of the close and personal relationship they had with the banker's employee accountant Hew in question. His Honour was also quite critical of the actions of the Bank and its accounting staff in allowing these transactions to occur. It is an important reminder to all organisations to ensure that they have the relevant compliance and risk management protocols in place and that these protocols are closely followed. ${ }^{41}$

(e) Seagate Technology Pte Ltd and Another v Goh Han Kim [1995] 1 SLR 17; [1994] SGCA 128

This matter was heard by the Singapore Court of Appeal. The judges were Justices of Appeal Karthigesu and Thean and Justice Goh Joon Seng. Justice Thean delivered the unanimous judgment of the Court. In this case, the auditors of the appellant company were summoned as witnesses in the court proceedings.

(i) Identification of the Types of Services Performed

The first appellant (originally the plaintiffs) is a company incorporated in Singapore and carrying on the business of manufacturing and repairing computer and data processing equipment and accessories. The respondent (originally the defendant) is a sole proprietor of a business that supplies goods to the first appellants.

They employed Heng as a planner and she was required to collate information on the usage requirements of materials, raising purchase requisitions and scheduling delivery of the required materials. The respondent was acquainted with Heng and met her once or twice a week.

In late 1986, Heng contacted with the respondent and asked him for a personal favour to help her Uncle in the United States, who was in financial difficulties. She said that her Uncle dealt in two products and that the first appellants used these products. Heng requested that the respondent purchase these products from her Uncle and then sell them to the first appellants. She agreed to provide him with a commission of $\$ 3$ per packet sold. She also told him that this arrangement was necessary as her uncle did not have a company in Singapore. The respondent

\footnotetext{
${ }^{40}$ See generally, C. Pacini, M. Martin and L. Hamilton, 'At the Interface of Law and Accounting: An Examination of a Trend toward a Reduction in the Scope of Auditor Liability to Third Parties in the Common Law Countries' (2000) 37(2) American Business Law Journal 171 - 236.

${ }^{41}$ S. Ghosh, 'Looking beyond Corporate Governance Code' (2007) 56(5) The Chartered Accountant 819-826.
} 
thought this was a genuine arrangement and obtained approval from the first appellant to supply materials to the first appellants.

Heng had devised a scheme where these products would be sent to the first appellant and then transferred and resent to the company again. This meant that the first appellant would be charged twice for the same products (once from the original supplier and again by the respondent). When the Audit team of Seagate Technology did not check on the deliveries, Heng did not include the physical goods, but merely book entries. To further evade the audit team, Heng would also amend the store's computer system that kept track of the deliveries. On 7 November 1988, the Seagate company's director of materials control carried out an audit and realised that the delivery orders had been altered. On 17 November, Heng and the respondent were interviewed and statements were taken from them both. On 21 November, the company commenced an action against Heng and the respondent claiming almost $\$ 2$ million for conspiracy to defraud and for moneys owed by them. The respondent counterclaimed for $\$ 366,864$ for goods supplied that had not been paid for.

Heng was convicted in December 1988 and was sentenced to three years' imprisonment. The first appellants were able to recover $\$ 942,000$ from Heng during this process. They then brought this action against the respondent for the remainder of the money (slightly over $\$ 1$ million).

\section{(ii) Identification of Financial Reporting Errors}

The financial report errors relevant to this case relate to a lack of independence and a failure of the Audit team and internal control systems of Seagate Technology Pte Ltd.

\section{(iii) Significance of the Financial Reporting/Advice Errors Identified}

Whilst this case does not directly consider the issue of auditor liability, it does make some important comments regarding the role of auditors in situations of employee fraud. In this case both the Judicial Commissioner and the Court of Appeal made numerous references to the first appellants' auditors. The Court of Appeal specifically stated 'that audit checks were carried out every month and that he discovered the first defendant's fraud 11 months after her scheme to cheat her 
employers was put into operation. ${ }^{42}$ This shows that when firms are subject to employee fraud, there auditing systems will be analysed to determine whether there were any systematic issues that may have allowed the fraud to continue unnoticed.

\section{(iv) Outcome or Conclusion in the Case}

The Court of Appeal outlined that transaction was quite peculiar due to the lack of documentation and formality however this was not sufficient to show an intention to defraud.

The Court of Appeal held that there was no conspiracy to defraud and that the action for moneys had and received must fail as the respondent had paid most of the money to Heng. Therefore, the respondent was not liable to pay those sums of money to the first appellants.

\section{(f) Go Dante Yap v Bank Austria Creditanstalt AG [2011] SGCA 39}

This case was heard in the Singapore Court of Appeal.

\section{(i) Identification of the Types of Services Performed}

The appellant Go Dante brought an action against the defendant (an Austrian incorporated bank operating in Hong Kong and Singapore) in respect of losses suffered on the plaintiff's investment portfolio following the Asian financial crisis of 1997 and 1998. The appellant's investment account was handled by the Vice President who is an accountant employed at the Bank. The appellant alleged that 16 investments made by the Bank and the loans drawn to finance them were not authorised by him. In the alternative, if the investments and loans had been properly authorised, the Go Dante argues that the accountant failed to advise him that it was imprudent to have maintained the investment portfolio that he had during the Asian financial crisis.

The employee accountant had monthly meetings with the appellant where she discussed the investment portfolio, reviewed the performance of his investments which included examining the projected returns from the investments. The accountant admitted that she failed to keep a complete record of the meetings that had taken place with the plaintiff. She did not take minutes of all the minutes and did not tape record the phone conversations either, even though it is standard practice of the Bank.

${ }^{42}$ Seagate Technology Pte Ltd and Another v Goh Han Kim [1995] 1 SLR 17, [40]. 


\section{(ii) Identification of Financial Reporting Errors}

There were two errors reported - firstly, the drawing of investments and loans without permission and secondly, the failure to warn of the specific risks of having the particular investment portfolio. There was also a potential third error, related to the failure to keep proper records of the meetings.

\section{(iii) Significance of the Financial Reporting/Advice Errors Identified}

The Appeal court found that there was sufficient proximity between the parties to give rise to a duty of care under the law of negligence on the respondent's part. In this case, the accountant accepted responsibility to control the appellant's portfolio of assets. In offering private banking and wealth management facilities, the accountant held herself out as possessing special skill or expertise to manage investments and transacting in emerging market securities or to search for and recommend such investments. The appellant customer placed implicit reliance on that expertise, in that he gave the respondent accountant authority to advise him in relation to the purchase of securities.

\section{(iv) Outcome or Conclusion in the Case}

For the above reasons, the Appeal Court found the respondent owed appellant a contractual duty of skill and care and a tortious duty to take reasonable care in rendering services to the customer. However, the court noted that it was open to banks to exclude or limit their duty of care via disclaimers or exclusion clauses in their account opening documents.

The next question was whether the accountant had breached her standard of care imposed in performing her services. The extent of the standard or care will largely be governed by the following factors:

- Prevailing circumstances and the danger of hindsight: The court pointed out that the situation in which the appellant entered in to investments in mid-1997 was one of extreme economic turbulence and turmoil. Given that the Asian Financial Crisis unfolded extremely quickly and caught even the world's best financial minds unaware, the bank advisor should not be judged with the benefit of hindsight.

- Experience and sophistication of the appellant customer: the customer was commercially confident and had sufficient knowledge of investment principles, and this would lower the standard of care expected from the bank advisor. 
- Contractual framework: under the terms of the contractual documentation which the bank and the customer entered into, the bank was not authorised to make investments or sell securities without the customer's permission. The customer maintained a significant degree of control over his accounts and investment portfolio, which also lowered the standard of care placed on the bank advisor.

After analysing the above factors, the court held that while the respondent owe a general duty of care and skill to customers, the respondent had not breached her standard of care in rendering her services to the appellant.

(g) Ikumene Singapore Pte Ltd \& Another $v$ Leong Chee Leng (trading as Elizabeth Leong \& Co) [1993] SGCA 50

This case was heard by the Singapore Court of Appeal. The judges were Yong Pung How CJ, Chao Hick Tin J and M Karthigesu J. Chao Hick Tin J delivered the decision of the court.

\section{(i) Identification of the Types of Services Performed}

The respondent (Ms Leong) was the auditor for the appellants. In order to secure overdraft facilities for Ikumene Pty Ltd, the second appellant acted as guarantor for the Ikumene company and executed a charge in favour of Far Eastern Bank Ltd on his fixed deposit of $\$ 200,000$ at the bank. The second appellant was also a shareholder in the company, having purchased $\$ 47,000$ shares. The second appellant therefore had two standings in the case (guarantor and individual shareholder).

The respondent audited three sets of accounts for the years 1979, 1980 and 1981 as per the Singapore Companies Act s 207(1), which requires that auditors 'report to the members on the accounts required to be laid before the company in general meeting and on the company's accounting and other records relating to those accounts.' Her reports stated that the accounts were properly drawn up.

After the auditor provided her report, the loan was provided (subject to the guarantee from the second appellant). The first appellant then defaulted on the loan and the bank then sent a letter to the second appellant demanding payment of almost $\$ 200,000$ (which increased due to interest requirements). 
The appellants sued Ms Leong for negligence alleging that she had not exercised reasonable care when she certified that the accounts gave a true and fair picture of the company's state of affairs.

\section{(ii) Identification of Financial Reporting Errors}

The relevant error was a failure to exercise reasonable care and skill when auditing the reports and declaring that they were properly drawn up. This was alleged because the auditor certified the accounts without 'adequate checking or verification.'

An accounting expert witness appointed by the appellant found an oversight by the respondent auditor where she did not include an item of purchase, thereby understated the loss by $\$ 15,479$ on the 1979 audited accounts. This amount is material to the 1979 accounts and with such understatement did not show a true and fair view.

The expert witness found several deficiencies in Ikumene Ltd's accounting records:

- the purchase ledger was not properly maintained. The totals for 1979 and 1981 did not agree with purchase accounts in the general ledger and were not written up contemporaneously;

- the stock cards for 1979 and 1980 had no cross-references to purchase and sale sources, no value balances for reconciliation to a stock control account in the general ledger which had no such account. There was no indication that the balance of stock shown on the cards had been checked with physical stock, some stock cards included a mix of different stock items. There was no clear distinction between stocks held for own account and stocks held on consignment;

- there was no debtors' ledger, no individual account for each debtor and receipts were not always issued for payments received;

- the cash book showed receipts improperly analysed to sundry income instead of debtors and payments improperly analysed to purchases instead of creditors.

\section{(iii) Significance of the Financial Reporting/Advice Errors Identified}

The alleged financial reporting errors were not considered in depth as the court was of the view that there was no proximity in relationship between the borrower company and the auditor and therefore no duty of care. When discussing 
proximity and causation issues, the court accepted that the respondent auditor did not act with adequate care and therefore breached her duty, but stated that:

we do not think it is sufficient for the appellants to merely show that the respondent did not carry out the audit with the degree of care expected of her as a professional auditor. Specific losses must be proved and those losses must also be proved to have been caused by the negligence of the respondent. ${ }^{43}$

Unfortunately, this finding means that there was no detailed consideration of the financial reporting errors identified.

\section{(iv) Outcome or Conclusion in the Case}

When determining the duty of care, the Appeal court closely followed the negligent misstatement cases of the House of Lords in UK. They stated that for the 'special relationship' of proximity to exist, it must be found that the maker of the statement was, or ought to have been, aware that his advice or information would in fact be made available to and be relied on by a particular person or class of persons for the purposes of a particular transaction or type of transaction.

The Court held that the provisions of the Companies Act established a relationship between the auditors and the shareholders of the company and the shareholders are entitled to rely on this for the protection of their interests. However, their Honours then stated that 'We do not think we should widen the scope of duty of an auditor to include the losses that may be suffered by a guarantor of a company; that is not a purpose for which the accounts are prepared.' They therefore held that there was no duty of care owed to the second appellant when standing as a guarantor. When standing as an individual shareholder, the court also held that there was no duty of care to the second appellant. Their Honours followed British court precedent and held that the duty owed by the auditor did not extend to an individual shareholder who sustained a loss in respect of the existing shareholding.

Whilst there was a duty of care owed to the company, the court held that the appellants could not show that there was causation between the auditor's breach and loss suffered. The appellants could not prove that they suffered specific losses caused by the negligence of the respondent. In fact, after the letter of demand of 18 August 1983 from the bank for payment of \$200,000, Ikumene had carried on trading profitably. The appellants did not satisfactorily establish that the losses claimed for were attributable to the period for which the respondent owed a duty

43 Ikumene Singapore Pte Ltd \& Another v Leong Chee Leng (trading as Elizabeth Leong \& Co) [1993] SGCA $50,[34]$. 
as the auditor of Ikumene. The court therefore held that the auditor was not liable for the losses suffered by the appellants.

\section{(h) PlanAssure PAC (formerly known as Patrick Lee PAC) v Gaelic Inns Pte Ltd [2007] 4 SLR 513; [2007] SGCA 41}

This case was heard by the Singapore Court of Appeal. The judges were Andrew Phang Boon Leong JA, Chan Sek Keong CJ, V K Rajah JA. V K Rajah JA delivered the decision of the court.

\section{(i) Identification of the Types of Services Performed}

The respondent Gaelic Inns Ltd is a business that owns and operates pubs in Singapore. The appellant is a firm of certified public accountants. The appellant was engaged by the plaintiff to conduct statutory audits in the financial years 2001 and 2003. The audits for the company for the FYs 2001 and 2002 were completed without any issues and the respondent retained the appellant's services for the audit in 2003. The audits were conducted in accordance with s 207(1) of the Companies Act and expressed an opinion as to whether the respondent's financial statements gave a true and fair view of the company's profit and loss.

Between 2001 and 2004 the respondent's finance manager developed a scheme to defraud the company of significant amounts of money. This scheme was known as 'teeming and lading' and involved taking money for personal benefit and making up the shortfall from cash collected from later sales. For a period of time, the actions occurred without detection and a total of $\$ 1,006,115.12$ was misappropriated. The scheme was eventually detected by the respondent's payroll and administration manager of Gaelic Inns Ltd.

The finance manager was charged and convicted on three criminal counts. Gaelic Inns Ltd was only able to recover $\$ 8,929$ compensation from the finance manager and $\$ 100,000$ from the insurers. The respondent therefore sued the appellant auditors for damages of almost $\$ 1,000,000$ for negligence in respect of the audits performed between 2002 and 2004, in particular for failure to detect the misappropriation of the funds in the 2001, 2002 and 2003 audits. The negligence was alleged to have caused losses at two levels. Firstly, it caused the respondent the loss of the opportunity to recover the misappropriated sums from the employee. Secondly, further misappropriations could have been avoided.

(ii) Identification of Financial Reporting Errors 
The alleged errors were a failure to exercise care due and skill during the audit. This included:

- a failure to inquire into the whereabouts of the 'un-credited lodgements';

- a failure to perform a cash count and roll-back; and

- failure to inquire into the circumstances surrounding the long list of reconciling items and the reasons why cash sales had not been regularly banked into the respondent's bank account in accordance with the respondent's banking policy.

- failure to reasonably suspect existence of fraud.

The specific allegations are therefore linked to a lack of independence of the auditor and an over-reliance on management representations. ${ }^{44}$ There was also failure to adequately scrutinise the internal systems which meant that the fraud went undetected for a significant period of time.

\section{(iii) Significance of the Financial Reporting/Advice Errors Identified}

The errors reported were quite significant and the Court of Appeal went into significant detail when analysing the financial reporting errors identified. The court noted that the Singapore Standards on Auditing (SSA 11 and SSA 240) specifically provide that an auditor must 'consider the risk of material misstatements in the financial statements resulting from fraud or error' when planning and performing audit procedures. As such, the court held that auditors will not be exempted from their duty to detect the existence of fraud and error.

The court held that the auditor had been put on inquiry in December 2003 as the bank reconciliation statement had clearly disclosed a substantial increase in unlodged cash deposit in comparison to those in previous years. By failing to inquire further into the reasons for the substantial increase, the auditor had failed to exercise the reasonable amount of care and skill expected of someone with his experience and qualification. The court also put a lot of importance in the fact that the auditor paid little attention to the flaws in the plaintiff's internal control system. For example, the auditor did not even place on record the existence of loopholes in the respondent's control system nor expressed any concerns about the increase in 'uncredited lodgement.'

The court placed a large amount of significance in the two stated errors and therefore found that the auditor had breached his duty to act with reasonable care and skill. 
On the other hand, the issue of 'contributory negligence' took a central role in this case. When the company's losses were occasioned by the acts of a third party, the court will look at the circumstances of each case to apportion the loss as between the company and its auditors.

The court found that the directors of Gaelic Inns to be 'contributorily negligent by reason of its own patent failure to safeguard its own interests,' and they had been guilty of serious maladministration of the company's affairs until 2004. The managing director was responsible for the day-today running of the company. He had confirmed receiving monthly bank reconciliation statements but never bothered to look at them. The managing director had admitted to not monitoring the company's banking procedures which were breached over time. As such, the management shortcomings of the directors had a direct impact on the court's determination as to contributory negligence on the part of Gaelic Inns.

\section{(iv) Outcome or Conclusion in the Case}

At the first trial, the judge noted that when an auditor's conduct is called into question, the court is required to decide on the legal duty of the auditor and why they are required to do in order to discharge the duty with reasonable skill and care. The determination of whether a breach had been made out depended on the facts of the case however the duty imposed could not exceed the task undertaken by the auditor. This means that the party making the allegation had to satisfy a two-fold requirement - show that the duty was owed to them and secondly that it was a duty in respect of the kind of loss that had been sustained.

Her Honour then commented that an auditor was 'not expected to be a detective,' but that if they uncovered matters which reasonably led to uncovering fraud, they were required to take further steps to inform management of the issue.

The trial judge then dismissed the plaintiff's claim for losses in FY 2001 and 2002. This was due to the fact that the misappropriation had covered by the practice of teeming and lading and therefore the plaintiff did not suffer any loss from the cash during this period. The judge did however found the appellant liable for breach of duty for the later audit. The auditor received a reconciliation statement for December 2003 which indicated substantial un-lodged cash deposits of $\$ 672,253.94$. This should have put the auditor on inquiry and the irregularity should have been investigated. Instead, the auditor waited for the bank statement and requested to be informed of the subsequent clearance dates. The trial judge

\footnotetext{
${ }^{44}$ See also, J. Stevenson, 'Auditor Independence: A Comparative Descriptive Study of the UK, France and Italy’ (2002) 6(2) International Journal of Auditing 155 - 182.
} 
therefore held that in failing to review the monthly bank reconciliations through 2003, the auditor had failed to discharge their duty and Gaelic Inns Ltd suffered financial detriment.

The auditor appealed this finding to the Court of Appeal. The court discussed the auditor's duties and stated that auditors 'must not certify what he does not believe to be true, and he must take reasonable care and skill before he believes that what he certifies is true. What is reasonable care in any particular case must depend upon the circumstances of that case. ${ }^{45}$ The justices of the appeal court agreed that in this case auditor had breached these duties as he had 'been conspicuously derelict in the discharge of its duties and could not possibly be said to have exercised reasonable care. ${ }^{46}$ The duties were breached in at least two material ways:

- Failure to understand the client's bank reconciliation statement and the meaning of the term 'un-credited lodgements'; and

- Failure to reasonably suspect existence of fraud.

The court also held that the auditor's breach of the duty of care had caused the harm suffered and therefore awarded damages of $\$ 634,216.05$ (reduced by 50 per cent for contributory negligence by the Gaelic Inns Pty Ltd) but nonetheless held that the auditors to be liable for only 50 per cent of the losses on account of the company's own negligence.

45 PlanAssure PAC (formerly known as Patrick Lee PAC) v Gaelic Inns Pte Ltd [2007] 4 SLR 513, [52].

${ }^{46}$ Ibid, [40]. 


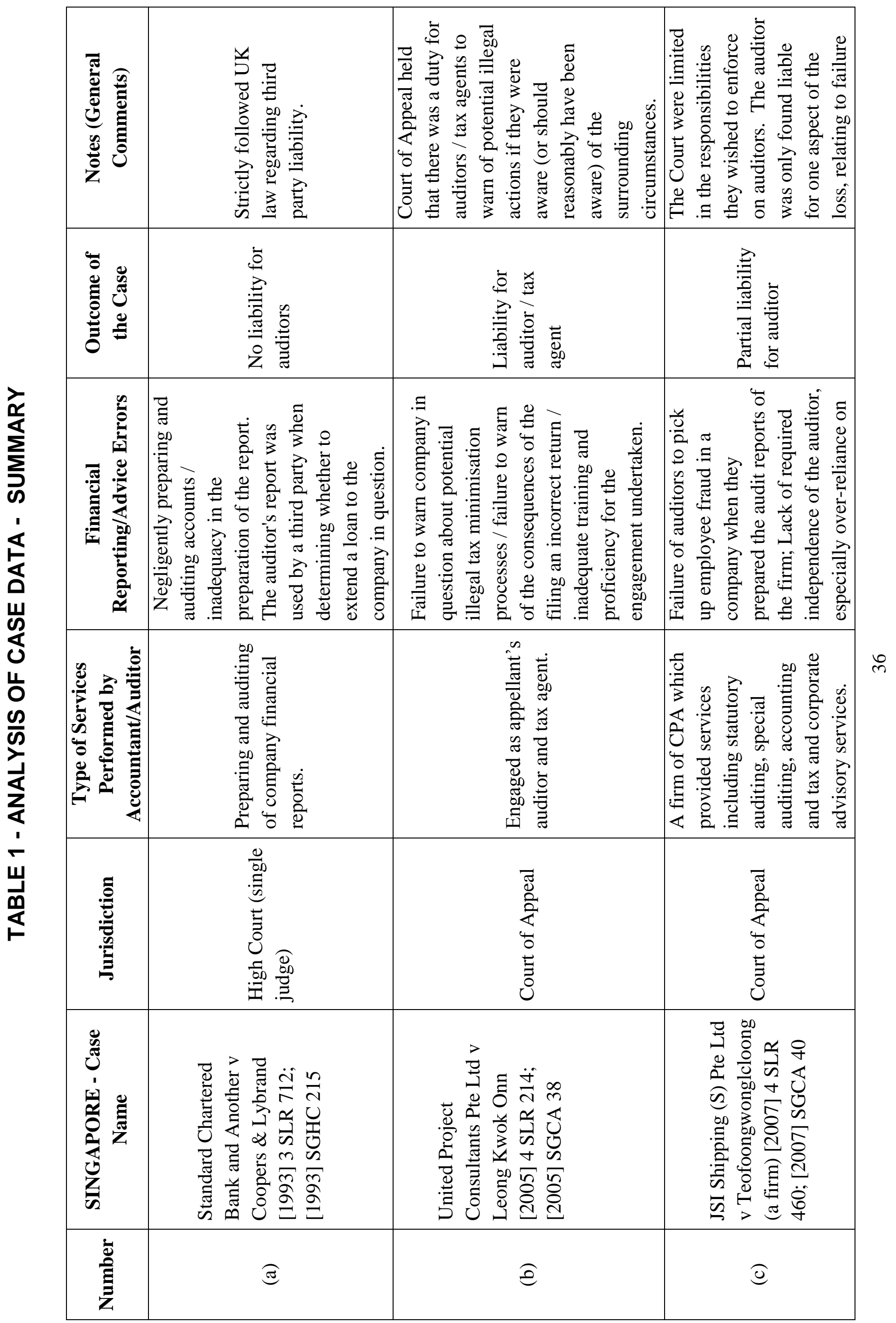




\begin{tabular}{|c|c|c|}
\hline 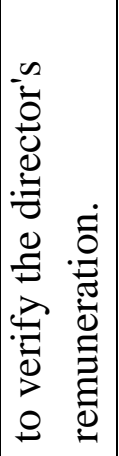 & 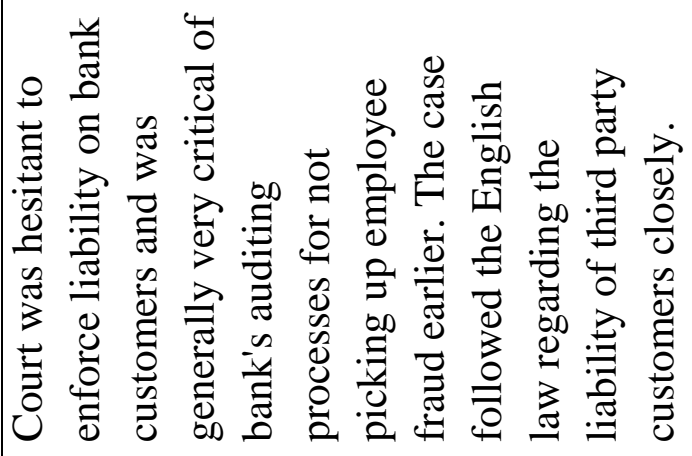 & 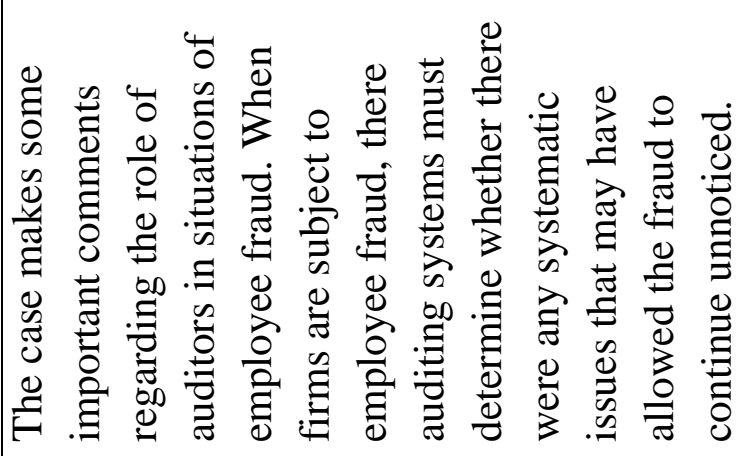 \\
\hline & 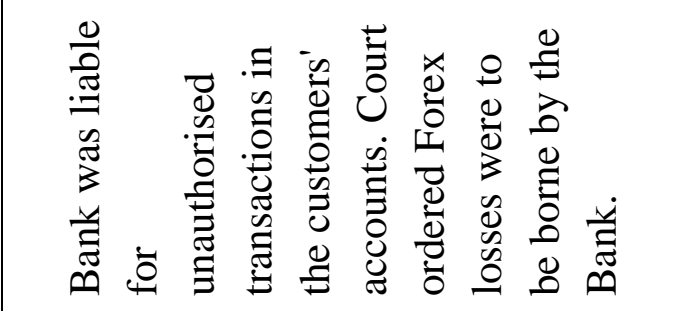 & 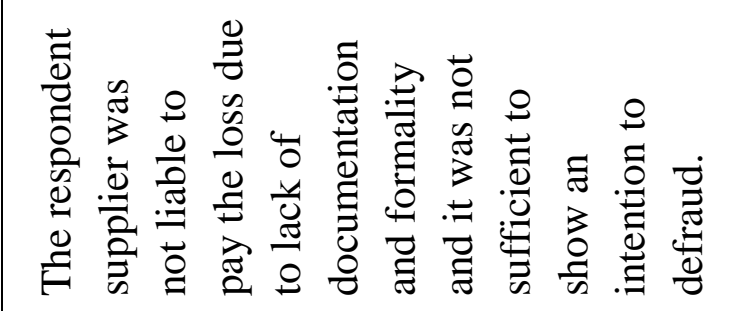 \\
\hline 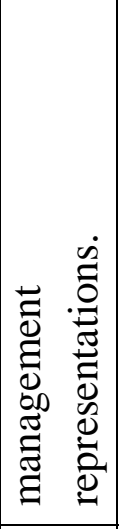 & 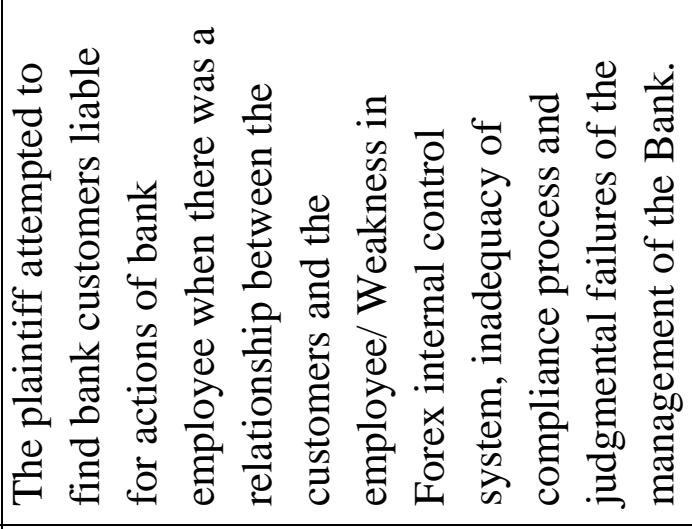 & 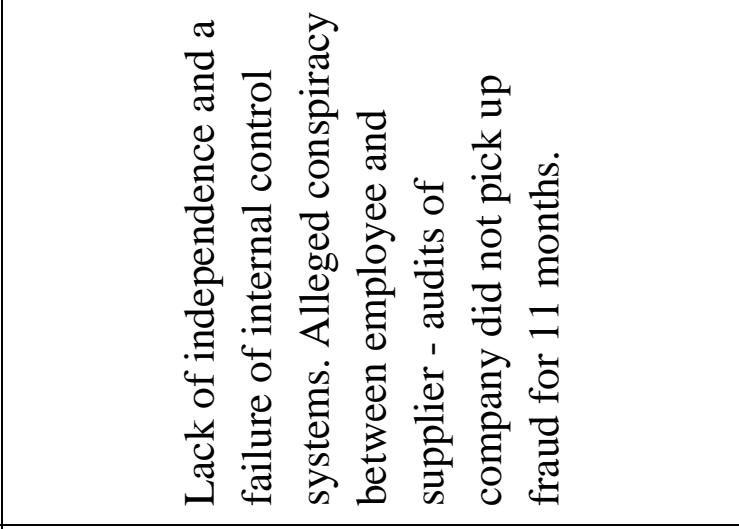 \\
\hline & 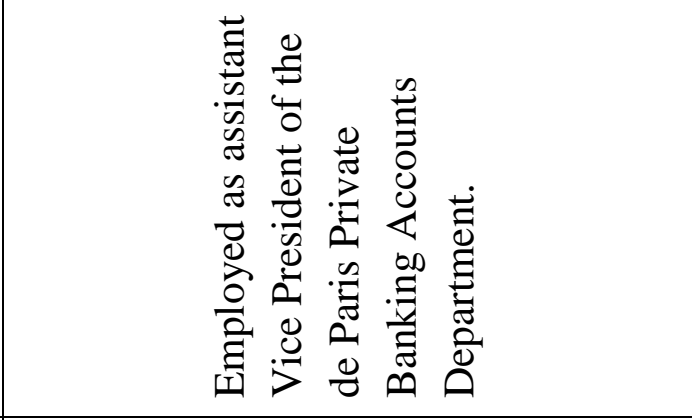 & 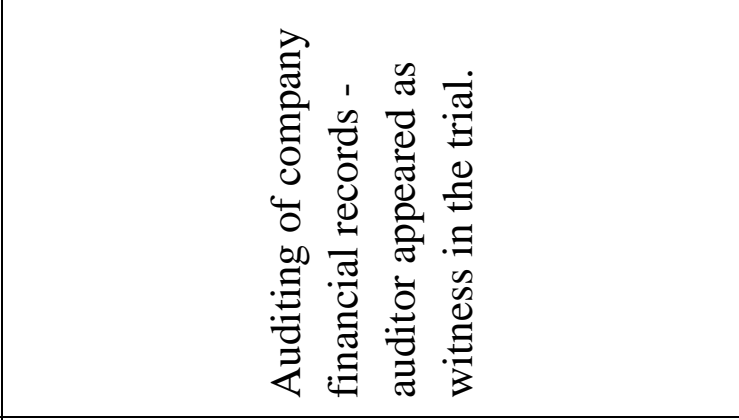 \\
\hline & 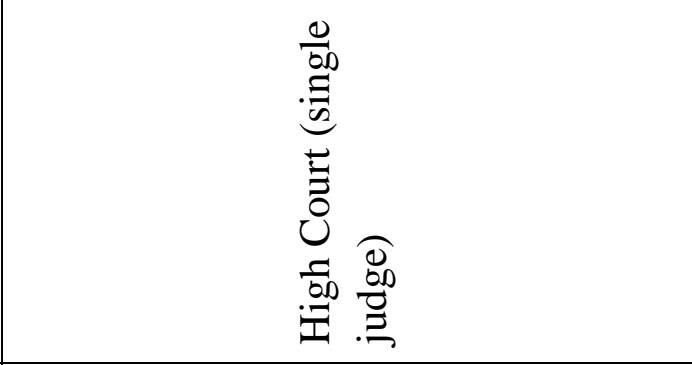 & 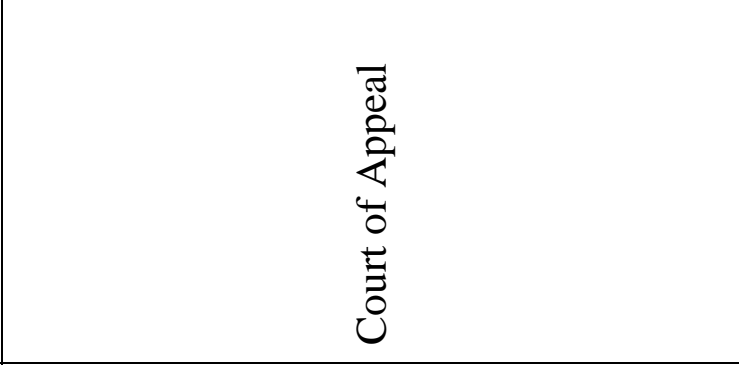 \\
\hline & 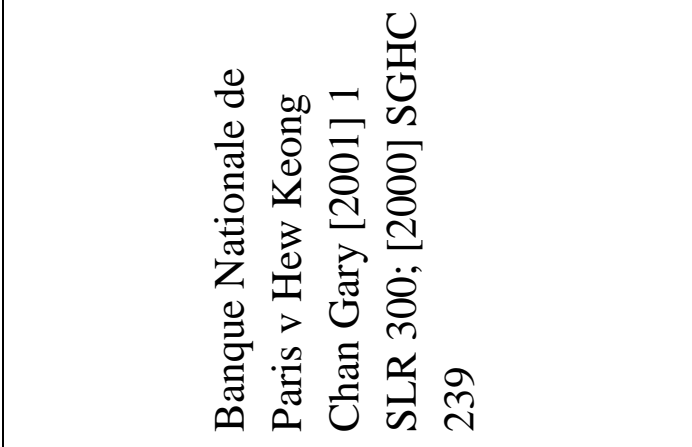 & 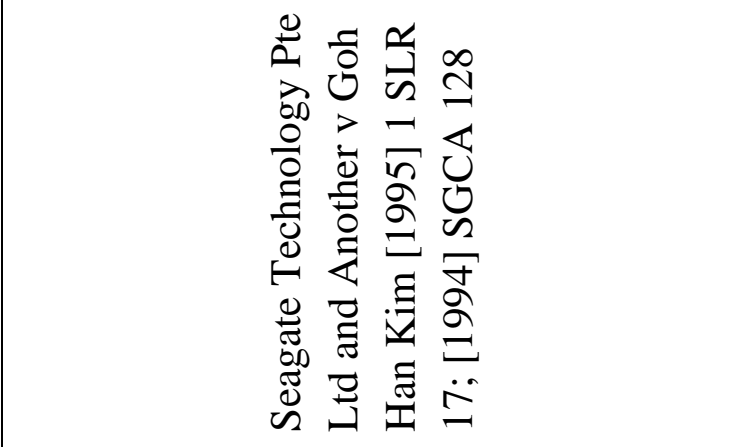 \\
\hline & (્) & (e) \\
\hline
\end{tabular}




\begin{tabular}{|c|c|}
\hline 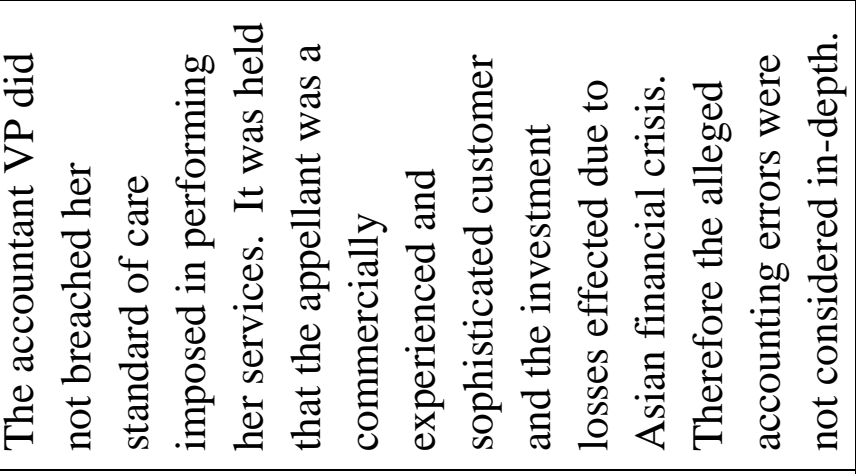 & 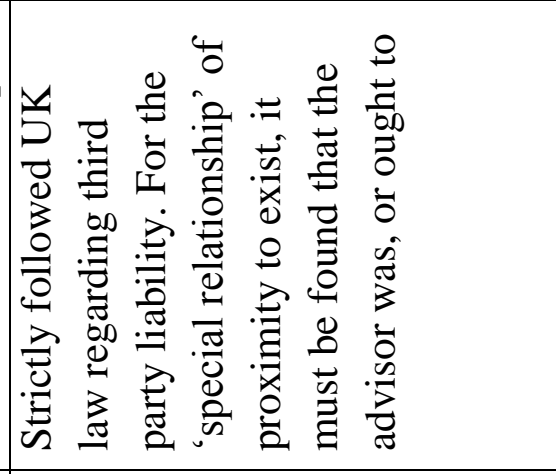 \\
\hline 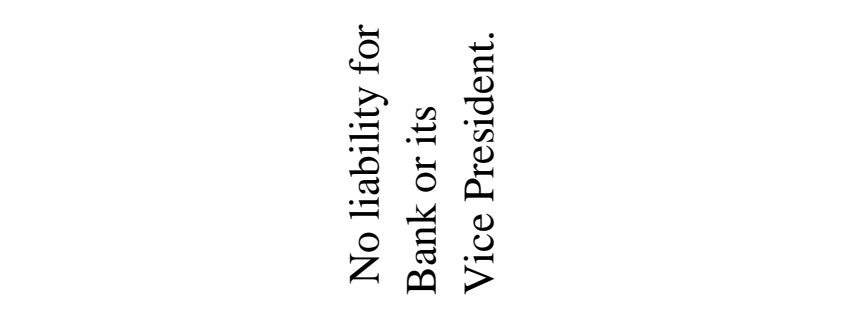 & 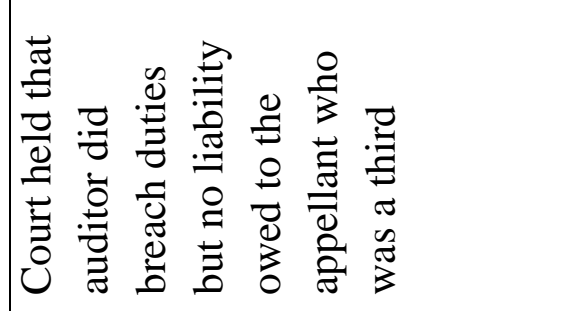 \\
\hline 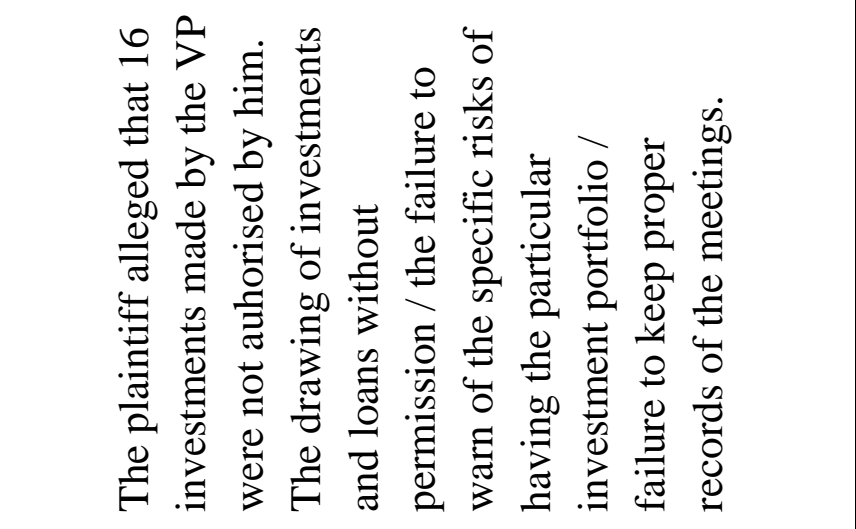 & 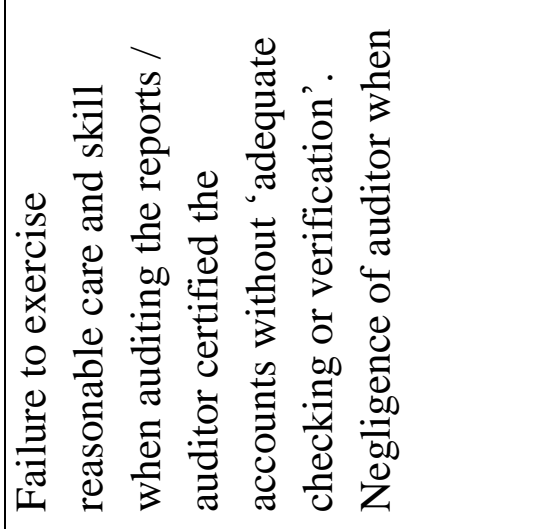 \\
\hline 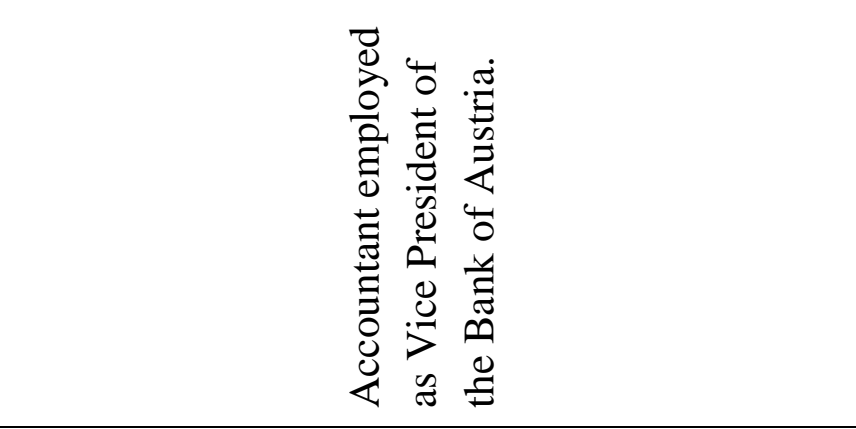 & 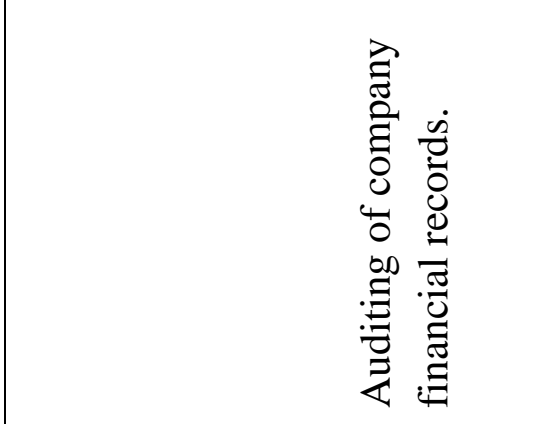 \\
\hline 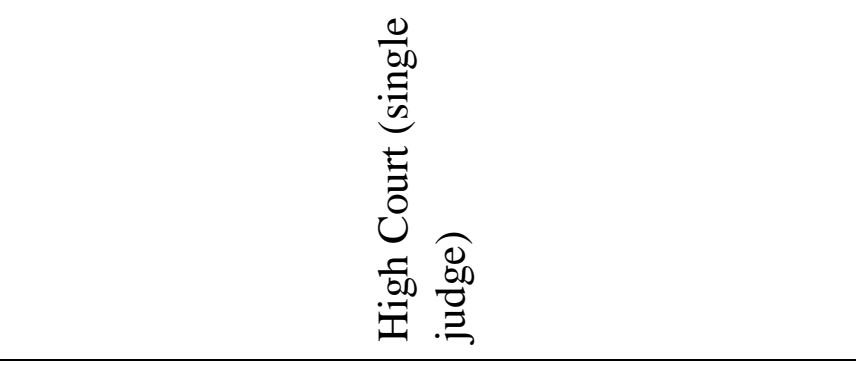 & 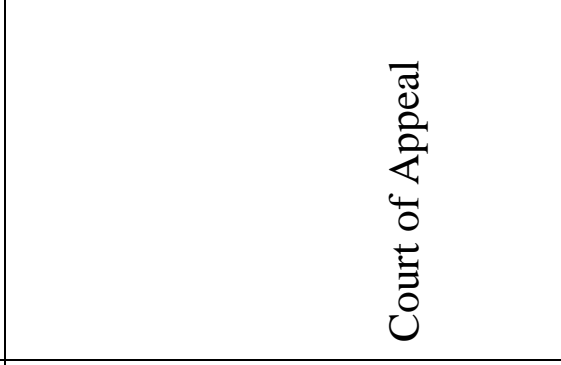 \\
\hline 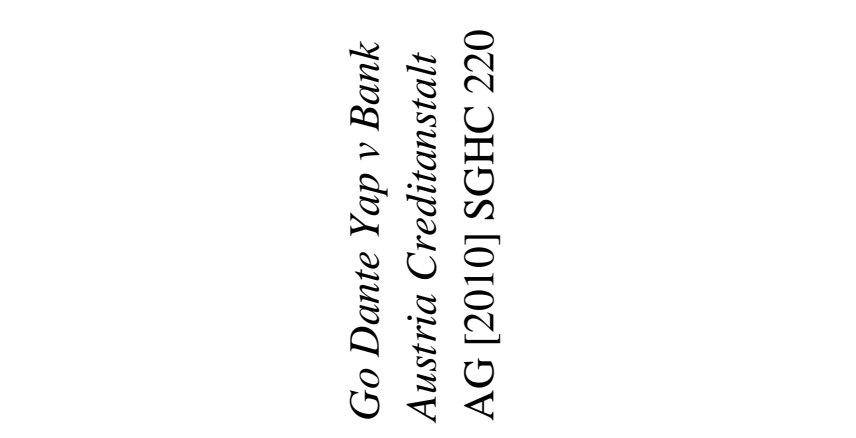 & 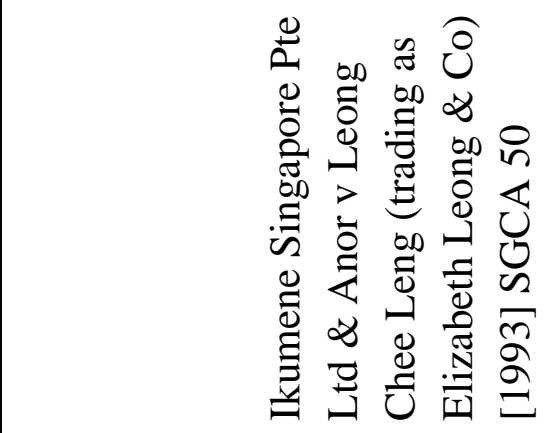 \\
\hline$\Theta$ & (6्रा \\
\hline
\end{tabular}




\begin{tabular}{|c|c|}
\hline 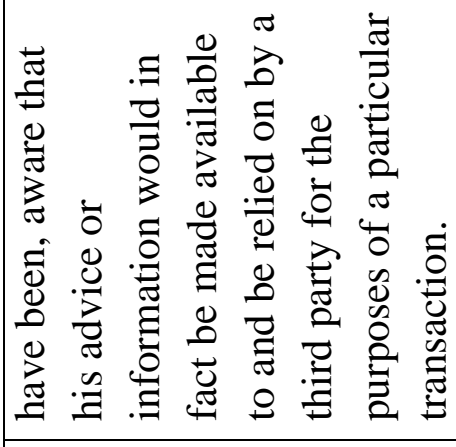 & 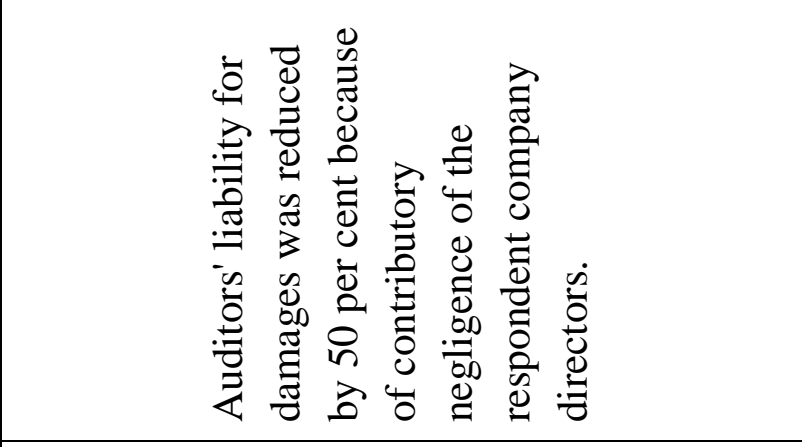 \\
\hline 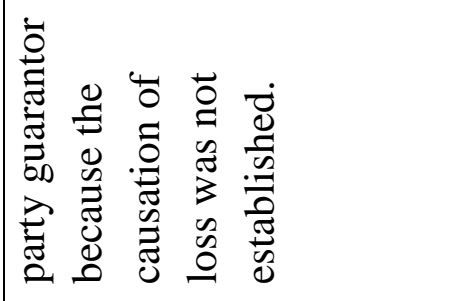 & 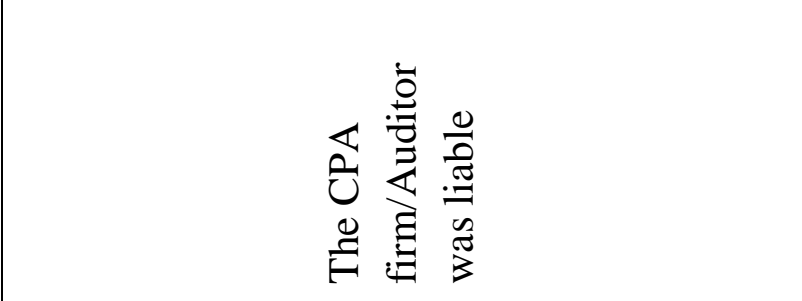 \\
\hline \multirow[t]{5}{*}{ 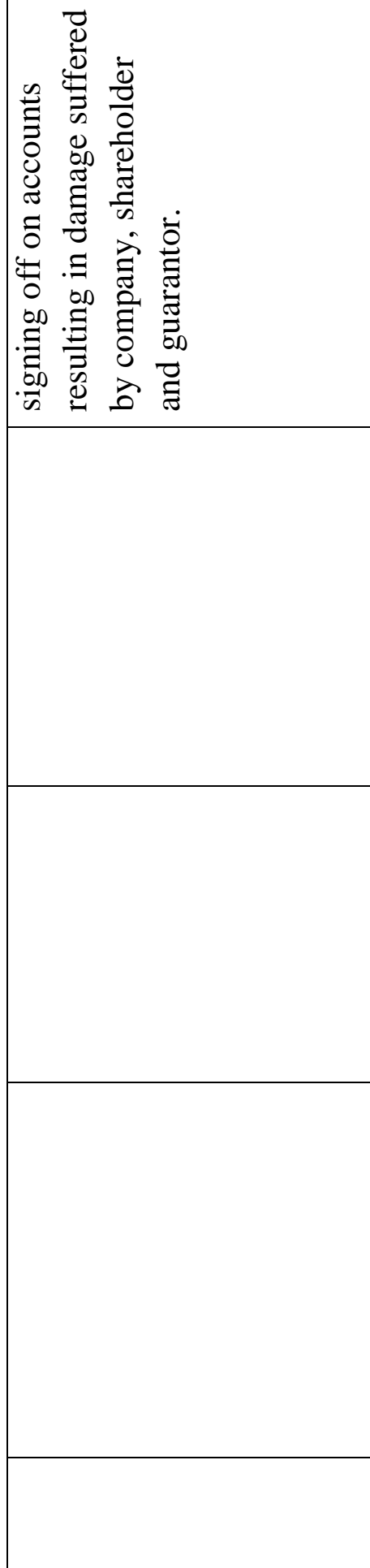 } & 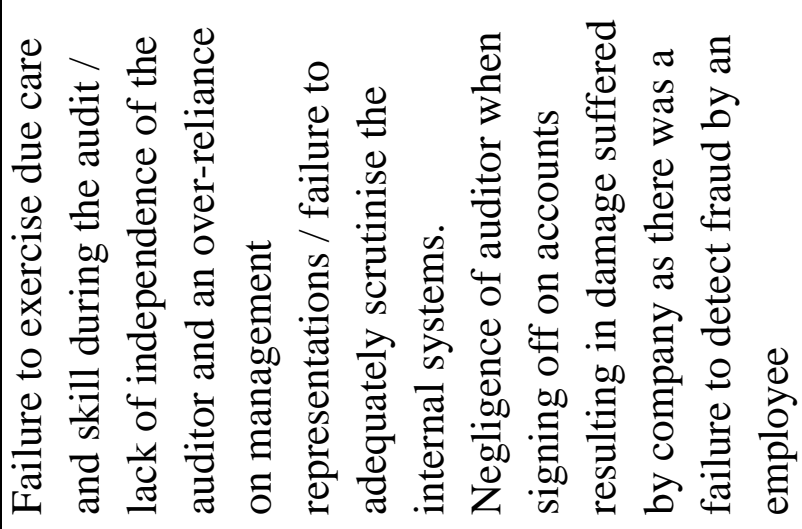 \\
\hline & 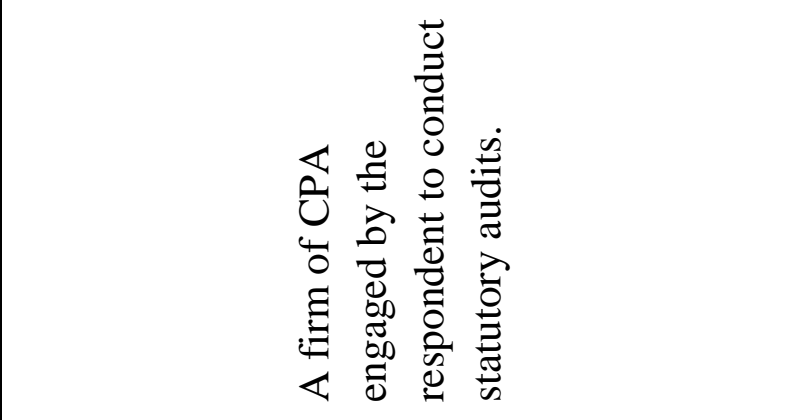 \\
\hline & 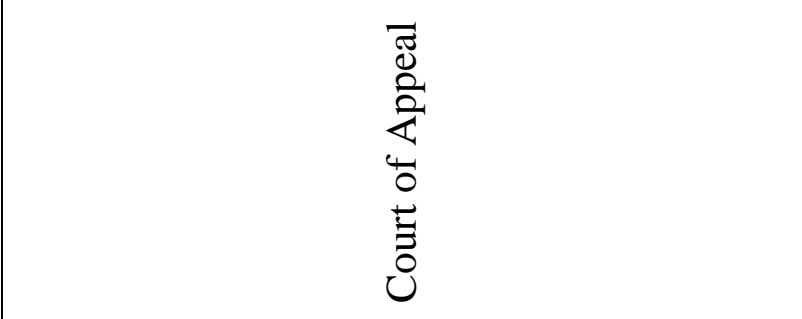 \\
\hline & 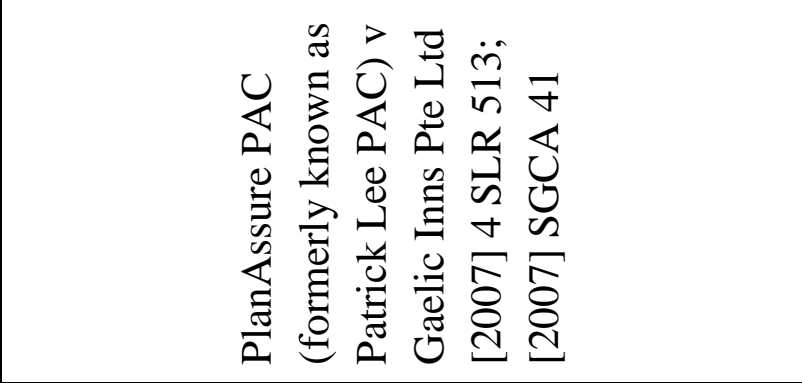 \\
\hline & こ \\
\hline
\end{tabular}




\section{Summary of the Case Analysis}

As shown in Table 1 above, there were a wide variety of main issues in the lawsuits for the courts. Employee fraud was the most common legal issue, with four out of eight cases considered involving an alleged failure of the defendant financial advisor to identify employee fraud in a company when it either audited the company or prepared reports for the firm. In the cases of this type that reached the courts, the plaintiff company was unable to recover the lost money from the employee (or was only able to recover a small amount of the money) and therefore sued the financial advisor for failing to identify the fraud and therefore allegedly causing the financial loss to the plaintiff company.

Another common issue was the failure of the financial advisor to adequately inspect the accounting and other records of the defendant company under the relevant provision of the Singapore Companies Act 1965. This accounted for three cases out of all cases analysed. The remainder of the cases dealt with a wide range of issues, including the:

- Use of auditor's financial report by a third party when determining whether to extend a loan to or invest in a company;

- Inability to fully understand the requirements of the Income Tax Act and a failure of the audit firm to warn of the consequences of the filing an incorrect return; failure to warn the plaintiff company about potential illegal tax minimisation processes;

- Negligent involvement in and failure to warn of risks of an investment opportunity - Plaintiff alleged that a number of investments made by the defendant financial advisor were not authorised by him; and/or the defendant failed to adequately warn him of the risk to his investment portfolio.

- Errors in performance of audit; lack of independence of auditor; failure of internal control mechanisms and inadequacy of the compliance process; inadequate training and proficiency for the engagement; inadequacy in the preparation of a financial report; failure to warn of the consequences or risks of transactions; inability to fully understand and appreciate the relevant legal requirements; and directors' breach of fiduciary duties. 


\section{CONCLUSION}

The above analysis of the lawsuits brought against the accountants and auditors reveals that the integrity and accuracy of financial statements is vital for good corporate governance because it concerns the relationships between corporate managers, directors and stakeholders. The assurance in corporate reporting and good governance practices are crucial for stability of financial system in Singapore. It is fair to say that some of the major causes of corporate accountability failures during the last two decades have been due to poor accounting and auditing standards, breach of auditing standards, and lack of cohesion between board, external auditors, internal auditors and the rest of management. The accounting profession has lost much of its credibility, public trust has been badly shaken, and the profession has learned the hard way that it should not take its position in society for granted. To minimise the chance of being exposed to litigation in the future it is important for the profession at large, to be aware of the different accounting processes and procedures, and to adopt best practice guidelines that are suited to the unique legal and commercial landscape in Singapore.

These recent decisions suggest a trend by the courts to impose strict duties of supervision on management and auditors. As a practical measure to avoid liability, and as a best practice, audit committees, boards and companies should maintain a rigorous system of audits and corporate governance, and to adhere scrupulously to such systems on a continuing basis. In Singapore, the Code of Corporate Governance 2012 ('the Code') requires all listed companies to have an audit committee, to disclose their corporate governance practices and to explain any deviations from the Code. ${ }^{47}$ There is still the ability for companies to deviate from the Code provided they explain these deviations. This loophole could be open to abuse and therefore should be carefully monitored. Therefore, the accounting and auditing profession as a whole could benefit from enhanced corporate governance requirements to ensure that there are clear and transparent governance structures in place.

47 See, Monetary Authority Singapore, MAS Issues Revised Code of Corporate Governance, (May 2012) $\langle$ http://www.mas.gov.sg/en/News-and-Publications/Press-Releases/2012/MAS-Issues-Revised-Code-ofCG.aspx $>$. 


\section{REFERENCES}

ACCA, Accountancy Future, Audit Reform: Aligning Risk with Responsibility (London: The Association of Chartered Certified Accountants, 2011) <http://www.accaglobal.com/content/dam/acca/global/.../tech-af-arar.pdf $>$.

Anderson, H., 'Auditors' Liability: Is Misleading and Deceptive Conduct an Alternative to Negligence?' (1999) 17(6) Companies and Securities Law Journal, 350-359.

Australian Treasury, Audit Quality in Australia: A Strategic Review (March 2010) $<$ http://www.archive.treasury.gov.au/contentitem.asp?ContentID=1745>.

Baxt, Robert, 'The Liability of Auditors - The Pendulum Swings Back' (1990) 8 Company and Securities Law Journal 249-57.

Bush, T., et al., Auditor Liability Reforms in the UK and the US: A Comparative Review (2007) <http://papers.ssrn.com/sol3/papers.cfm?abstract>.

Carl, P., William, H. and S. David, 'Auditor liability to third parties: an international focus’ (2000) 15(8) Managerial Auditing Journal 394 - 407.

Chua, S., 'More Thoughts on the Auditor's Liability in Negligence in respect of the Audit Report' (1995) 16(7) Company Lawyer 195-201.

Cooper, K., 'Proportionate Liability- 5 years on' (A paper presented for The Continuing Professional Education Department of the College of Law, Sydney, 2010) 8 - 15.

Davidson A. and A. Khan, 'Contractual Liability of an Auditor.' (1980) 8(5) Australian Business Law Review 300-309.

Davies, M., 'The Liability of Auditors to Third Parties in Negligence' (1991) 14(1) University of New South Wales Law Journal 171 - 192.

De Poorter, Ingrid, 'Auditor's liability towards third parties within the EU: A comparative study between the United Kingdom, the Netherlands, Germany and Belgium' (2008) 3(1) Journal of International Commercial Law and Technology $68-75$. 
Duffy, M., 'Proportionate Liability: A Disproportionate and Problematic Reform' (2003) 60(8) Plaintiff 11-20.

Free, Clinton, 'Limiting Auditors' Liability' (1999) 11(1) Bond Law Review 118.

Ghosh, S. 2007, 'Looking beyond Corporate Governance Code' (2007) 56(5) The Chartered Accountant 819-826.

Gill, G. et al., Modern Auditing in Australia (NSW: John Wiley and Sons, $6^{\text {th }}$ ed., 2007).

Greinke, A, 'Auditors' Liability to Third Parties: The View of the High Court' (1997) 15(5) Company and Securities Law Journal 309-313.

Hogg, K., 'The Tortious Liability of Auditors to Third Parties: A Reassessment.' (1994) 18(1) University of Queensland Law Journal 79-93.

Jain, Ameeta and Dianne Thomson, 'Corporate Governance, Board Responsibilities and Financial Performance: The National Bank of Australia' (2008) 6(2) Corporate Ownership \& Control 99-113.

Kan, Ernest, Audit and Assurance - Principles and Practices in Singapore (CCH Asia Pte Limited, $2^{\text {nd }}$ ed., 2010).

Khoury, L., 'The Liability of Auditors Beyond Their Clients: A Comparative Study' (2001) 46 McGill Law Journal 413 - 472.

Monetary Authority of Singapore, Code of Corporate Governance 2012, <http://www.mas.gov.sg/en/News-and-Publications/Press-Releases/2012/MASIssues-Revised-Code-of-CG.aspx $>$.

Nguyen, Vylan and Pelma Rajapakse, 'An Analysis of the Auditors' Liability to Third Parties in Australia' (2008) 37 Common Law World Review 9-24.

Pacini, C., Martin, M., and Hamilton, L., 'At the Interface of Law and Accounting: An Examination of a Trend toward a Reduction in the Scope of Auditor Liability to Third Parties in the Common Law Countries' (2000) 37(2) American Business Law Journal $171-236$. 
Rajacic, Maggie, Pelma Rajapakse and Eileen Webb, 'The Impact of the Trade Practices Act (1974 (Cth) on the Auditors' Liability' (2000) 19 University of Tasmania Law Review 205-236.

Stevenson, J., 'Auditor Independence: A Comparative Descriptive Study of the UK, France and Italy' (2002) 6(2) International Journal of Auditing 155 - 182.

Treasury, Australian Auditor Independence Requirements (2006), $<$ http://archive.treasury.gov.au/documents/1184/PDF/Australian_Auditor_Independ ence_Requirements.pdf $>$.

United Kingdom Parliament Economic Affairs Committee, Auditors: Market Concentration and their Role (2011), $<$ http://www.publications.parliament.uk/pa/ld201011/ldselect/ldeconaf/119/11903.h $\underline{\mathrm{tm}}>$. 